Atmos. Chem. Phys., 13, 2283-2297, 2013

www.atmos-chem-phys.net/13/2283/2013/

doi:10.5194/acp-13-2283-2013

(c) Author(s) 2013. CC Attribution 3.0 License.

\title{
CCN activity and volatility of $\beta$-caryophyllene secondary organic aerosol
}

\author{
M. Frosch ${ }^{1, *}$, M. Bilde ${ }^{1}$, A. Nenes ${ }^{2,3}$, A. P. Praplan ${ }^{4, * *}$, Z. Jurányi ${ }^{4, * * *}$, J. Dommen ${ }^{4}$, M. Gysel ${ }^{4}$, E. Weingartner ${ }^{4}$, and \\ U. Baltensperger ${ }^{4}$ \\ ${ }^{1}$ Department of Chemistry, University of Copenhagen, Copenhagen, Denmark \\ ${ }^{2}$ School of Earth \& Atmospheric Sciences, Georgia Institute of Technology, Atlanta, GA, USA \\ ${ }^{3}$ School of Chemical and Biomolecular Engineering, Georgia Institute of Technology, Atlanta, GA, USA \\ ${ }^{4}$ Laboratory of Atmospheric Chemistry, Paul Scherrer Institute, Villigen, Switzerland \\ * now at: Division of Nuclear Physics, University of Lund, Lund, Sweden \\ ** now at: Division of Atmospheric Sciences, Department of Physics, University of Helsinki, Helsinki, Finland \\ *** now at: School of Engineering, Institute of Aerosol and Sensor Technology, University of Applied Sciences Northwestern \\ Switzerland, Windisch, Switzerland
}

Correspondence to: M. Frosch (miafrosch@gmail.com)

Received: 4 July 2012 - Published in Atmos. Chem. Phys. Discuss.: 17 August 2012

Revised: 10 February 2013 - Accepted: 11 February 2013 - Published: 27 February 2013

\begin{abstract}
In a series of smog chamber experiments, the cloud condensation nuclei (CCN) activity of secondary organic aerosol (SOA) generated from ozonolysis of $\beta$ caryophyllene was characterized by determining the $\mathrm{CCN}$ derived hygroscopicity parameter, $\kappa_{\mathrm{CCN}}$, from experimental data. Two types of CCN counters, operating at different temperatures, were used. The effect of semi-volatile organic compounds on the CCN activity of SOA was studied using a thermodenuder.

Overall, SOA was only slightly CCN active (with $\kappa_{\mathrm{CCN}}$ in the range $0.001-0.16$ ), and in dark experiments with no $\mathrm{OH}$ scavenger present, $\kappa_{\mathrm{CCN}}$ decreased when particles were sent through the thermodenuder (with a temperature up to $50{ }^{\circ} \mathrm{C}$ ).

SOA was generated under different experimental conditions: In some experiments, an $\mathrm{OH}$ scavenger (2-butanol) was added. SOA from these experiments was less $\mathrm{CCN}$ active than SOA produced in experiments without an $\mathrm{OH}$ scavenger (i.e. where $\mathrm{OH}$ was produced during ozonolysis). In other experiments, lights were turned on, either without or with the addition of $\mathrm{HONO}(\mathrm{OH}$ source). This led to the formation of more $\mathrm{CCN}$ active SOA.

SOA was aged up to $30 \mathrm{~h}$ through exposure to ozone and (in experiments with no $\mathrm{OH}$ scavenger present) to $\mathrm{OH}$. In all experiments, the derived $\kappa_{\mathrm{CCN}}$ consistently increased with time after initial injection of $\beta$-caryophyllene, show-
\end{abstract}

ing that chemical ageing increases the $\mathrm{CCN}$ activity of $\beta$ caryophyllene SOA. $\kappa_{\mathrm{CCN}}$ was also observed to depend on supersaturation, which was explained either as an evaporation artifact from semi-volatile SOA (only observed in experiments lacking light exposure) or, alternatively, by effects related to chemical composition depending on dry particle size.

Using the method of Threshold Droplet Growth Analysis it was also concluded that the activation kinetics of the SOA do not differ significantly from calibration ammonium sulphate aerosol for particles aged for several hours.

\section{Introduction}

Aerosol particles play an important role in global climate both by interacting directly with solar radiation and through their ability to take up water and form cloud droplets, i.e. act as cloud condensation nuclei $(\mathrm{CCN})$. The latter is referred to as the indirect aerosol effect (IPCC, 2007). The ability of particles to act as $\mathrm{CCN}$ depends on their size and chemical composition. Radiative properties of clouds are influenced by the size and number concentration of the individual cloud droplets, which is a function of the amount of water available and the number concentration of $\mathrm{CCN}$. 
Atmospheric aerosol particles are composed of inorganic as well as organic compounds. In many locations, organic material comprises a significant fraction (up to $90 \%$ ) of the total aerosol mass (Kanakidou et al., 2005; Jimenez et al., 2009). The organic components are introduced either through primary emissions or as secondary material. Secondary organic aerosol (SOA) is created through condensation of products from gas phase oxidation of volatile organic compounds (VOC), which can be of either biogenic or anthropogenic origin. Emissions of VOC are estimated to be more than $1000 \mathrm{Tg} \mathrm{C} \mathrm{yr}^{-1}$, the majority being biogenic (Guenther et al., 1995; Goldstein and Galbally, 2007). The contribution of SOA to the total amount of organic carbon in the aerosol phase is significant (e.g. Kanakidou et al., 2005; Goldstein and Galbally, 2007; Hallquist et al., 2009), but has a strong seasonal dependency (Kleindienst et al., 2007). Monoterpenes, such as $\alpha$-pinene, are among the most important biogenic SOA precursors (Kanakidou et al., 2005). The contribution of sesquiterpenes, such as $\beta$-caryophyllene, to the total VOC emissions is smaller (Griffin et al., 1999), but due to high aerosol yields from sesquiterpene oxidation, their contribution to SOA can be significant (e.g. Griffin et al., 1999; Sakulyanontvittaya et al., 2008).

Products from oxidation of $\beta$-caryophyllene have been the focus of previous studies (e.g. Jaoui et al., 2003; Lee et al., 2006; Chan et al., 2011; Hamilton et al., 2011; Jenkin et al., 2012). Since sesquiterpenes contain one more isoprene unit than monoterpenes, oxidation products of sesquiterpenes generally have a higher number of carbon atoms and a higher molar mass. It has been shown that both the aerosol yield and physical properties, such as hygroscopicity and CCN activity, of SOA depend strongly on experimental conditions (Donahue et al., 2005; Huff-Hartz et al., 2005; Asa-Awuku et al., 2009; Alfarra et al., 2012; Tang et al., 2012). For example, the aerosol yield from photo-oxidation of $\beta$-caryophyllene is much greater than the yield from ozonolysis without light exposure (Hoffmann et al., 1997; Griffin et al., 1999), indicating that increased levels of $\mathrm{OH}$ during photolysis favor production of low-volatility species. As another example, SOA generated in the presence of an $\mathrm{OH}$ scavenger (2-butanol) has a much lower CCN activity than SOA generated in the presence of $\mathrm{OH}$ (Asa-Awuku et al., 2009; Tang et al., 2012).

Compared to SOA from other terpenes, CCN activity of SOA from $\beta$-caryophyllene is quite low. The $\mathrm{CCN}$-derived hygroscopicity parameter $\kappa$ (Petters and Kreidenweis, 2007; see also Sect. 2) for $\beta$-caryophyllene SOA is $<0.05$ (HuffHartz et al., 2005; Asa-Awuku et al., 2009; Alfarra et al., 2012), which for example is lower than the $\mathrm{CCN}$ derived $\kappa$ of $\sim 0.1$ which has been reported for $\alpha$-pinene (e.g. Prenni et al., 2007; Duplissy et al., 2008; Jurányi et al., 2009; Frosch et al., 2011a). However, CCN activity of $\beta$-caryophyllene SOA from smog chamber experiments is reported to depend on the initial precursor concentration, being higher for lower concentrations (Tang et al., 2012), similar to the findings for $\alpha$ pinene SOA (e.g. Duplissy et al., 2008). As mentioned above,
SOA from oxidation of $\beta$-caryophyllene is expected to be of higher average molar mass with a lower oxygen-to-carbon ratio and therefore also less water soluble and less $\mathrm{CCN}$ active than SOA from monoterpenes (Huff-Hartz et al., 2005).

Asa-Awuku et al. (2009) studied CCN activity of $\beta$ caryophyllene SOA using two different $\mathrm{CCN}$ counters (CCNC) and found that CCN activity was greater when measured with a static diffusion (SD) CCNC than when measured with a continuous flow (CF) CCNC. This difference was related to the different operating temperatures in the two instruments: The SD-CCNC operated close to room temperature, whereas the temperature in the CF-CCNC was above room temperature, the degree of which depended on the supersaturation. It was recently shown that $\beta$-caryophyllene SOA contains volatile or semi-volatile material (Asa-Awuku et al. 2009; Tang et al., 2012), which at elevated temperature may evaporate from the particles passing through the heated growth chamber of the CF-CCNC, and that the residual components were not only less volatile but also less hygroscopic than the evaporated fraction (Asa-Awuku et al., 2009). Relations between volatility and hygroscopicity of SOA produced in smog chambers have been examined by e.g. Tritscher et al. (2011), who suggested that simultaneous increases in volatility and hygroscopicity were the result of fragmentation of oxidation products, resulting in highly functionalized species with low molecular weight.

The connections between volatility and CCN activity of SOA have been the focus of previous studies, e.g. by Kuwata et al. (2011) who used a thermodenuder (TD) to study volatility effects of SOA produced from ozonolysis of $\alpha$ pinene in a continuous-flow chamber at different steadystate organic particle mass concentrations ( $M_{\text {org }}$, in the range $\left.1.4-37 \mu \mathrm{g} \mathrm{m}^{-3}\right)$. They found that while chemical composition (characterized by oxygen-to-carbon and hydrogen-tocarbon ratios, measured with aerosol mass spectrometry) depended solely on the post-TD $M_{\mathrm{org}}$, the behavior of CCN activity was more complex. At room temperature, $\mathrm{CCN}$ activity was independent of $M_{\mathrm{org}}$, with $\kappa$ values of approximately 0.1 . However, after passing particles through a TD with an elevated temperature $\left(100^{\circ}\right), \mathrm{CCN}$ activity decreased with increasing $M_{\mathrm{org}}$. A hypothesis to explain these observations was an increased fraction of oligomers in the particles. This increase was attributed partially to evaporation of highvolatility monomers and partially to particle-phase reactions favored at high values of $M_{\text {org }}$. For example, reactions such as aldol condensation, acid dehydration and hemiacetal formation, resulting in products with higher molar mass than the reactants, are favored in a warm TD, due to higher reaction rates at elevated temperatures (Jang and Kamens, 2001; Gao et al., 2004; Kuwata et al., 2011). Thus, as also observed by Tritscher et al. (2011), fragmentation is not the only chemical process responsible for changes in volatility and hygroscopicity. Oligomerization and changes in functionalization also affect physical properties of SOA. 
The less volatile material in $\beta$-caryophyllene SOA has been found to impact droplet growth kinetics (Asa-Awuku et al., 2009), possibly a consequence of soluble material evaporating from the particle surface and a redistribution of amorphous, "waxy" material in the surface of the activating droplet. Variations in droplet growth kinetics were related to the fraction of water-soluble organic material, which combined with the semi-volatile fraction of $\beta$-caryophyllene SOA - could have several atmospheric implications (Nenes et al., 2001; Raatikainen et al., 2012). For example, the semivolatile material could evaporate from particles with delayed water uptake and activation during warm days, causing a diurnal variation in CCN activity (Asa-Awuku et al., 2009).

In this work, $\mathrm{CCN}$ activity and volatility of SOA from $\beta$ caryophyllene are characterized in a series of smog chamber experiments. Particles were generated under different experimental conditions: ozonolysis with or without an $\mathrm{OH}$ scavenger, and ozonolysis under light exposure with an increased $\mathrm{OH}$ level from ozone photolysis. Additionally, some experiments were conducted with a strong $\mathrm{OH}$ source (photolysis of HONO). In all experiments, the initial concentration of $\beta$-caryophyllene was $25 \mathrm{ppb}$. Similar to the strategy of AsaAwuku et al. (2009), CCN activity was determined with two different $\mathrm{CCN}$ counters operating at different temperature. Connections between volatility, $\mathrm{CCN}$ activity and $\mathrm{OH}$ exposure were explored with a TD. Finally, droplet activation kinetics was explored using $\mathrm{CCN}$ activation measurements.

\section{Theory}

The equilibrium supersaturation of water (SS) for an aqueous solution droplet with known size and chemical composition can be determined using the Köhler equation (Köhler, 1936). Here we express it in the following way (Seinfeld and Pandis, 1998),

$S S=\frac{p}{p_{0}}-1=a_{\mathrm{w}} \cdot \exp \left(\frac{4 v_{\mathrm{w}} \sigma_{\mathrm{al}}}{R T D_{\mathrm{p}}}\right)-1$

where $a_{\mathrm{w}}$ is the water activity, $v_{\mathrm{w}}$ is the partial molar volume of water, approximated with the ratio of the molar mass, $M_{\mathrm{w}}$, to the density, $\rho_{\mathrm{w}}$, of water, $\sigma_{\mathrm{al}}$ is the air-liquid surface tension, $R$ is the ideal gas constant, $T$ is absolute temperature, and $D_{\mathrm{p}}$ is droplet diameter. The maximal $S S$ in dependence of $D_{\mathrm{p}}$ defines the so-called critical supersaturation, $S S_{\mathrm{c}}$.

Several one-parameter approaches exist to describe the concentration dependence of water activity and thereby the relationship between dry particle size and water uptake, for example the effective number of moles of soluble ions or non-dissociating molecules per dry particle volume (Rissler et al., 2006) or the ionic density $\rho_{\text {ion }}$ (Wex et al., 2007). Here we apply the widely used hygroscopicity parameter, $\kappa$, introduced by Petters and Kreidenweis (2007),

$\frac{1}{a_{\mathrm{w}}}=1+\kappa \frac{V_{\mathrm{s}}}{V_{\mathrm{w}}}$ where $V_{\mathrm{S}}$ is the solute volume (assumed to be dry particle volume) and $V_{\mathrm{w}}$ is the water volume. The most hygroscopic species found in ambient aerosols $(\mathrm{NaCl})$ have a maximum $\kappa$ of $\sim 1.3$, whereas $\kappa=0$ indicates that the particle is insoluble in water. Combining Eqs. (1) and (2) yields the equation defining “ $\kappa$-Köhler theory" (Petters and Kreidenweis 2007);

$S S=\frac{D_{\mathrm{p}}^{3}-D_{\mathrm{dry}}^{3}}{D_{\mathrm{p}}^{3}-D_{\mathrm{dry}}^{3}(1-\kappa)} \cdot \exp \left(\frac{4 M_{\mathrm{w}} \sigma_{\mathrm{al}}}{R T \rho_{\mathrm{w}} D_{\mathrm{p}}}\right)-1$

where $D_{\text {dry }}$ is the diameter of the dry particle. $\kappa$ can be determined from equilibrium growth factors $(G F)$ as well as from critical dry diameters or supersaturations measured at sub- and supersaturated conditions, respectively. The latter is referred to as the $\mathrm{CCN}$ derived hygroscopicity parameter, $\kappa_{\mathrm{CCN}}$.

\section{Experimental}

\subsection{SOA formation from $\beta$-caryophyllene}

The $\beta$-caryophyllene experiments were carried out in MayJune 2009 at the Paul Scherrer Institute (PSI) in a $27 \mathrm{~m}^{3}$ teflon reaction chamber (described in detail by Paulsen et al., 2005). Twelve ozonolysis experiments were carried out (see Table 1): two experiments in which 2-butanol was added to act as an $\mathrm{OH}$ scavenger ( $\mathrm{a}$ and $\mathrm{b}$ ), three experiments without addition of an $\mathrm{OH}$ scavenger leading to $\mathrm{OH}$ radical reactions as long as ozonolysis occurred (c-e); two with lights turned on leading to $\mathrm{OH}$ production from ozone photolysis ( $\mathrm{f}$ and $\mathrm{g}$ ), and five with lights and the addition of HONO (h-l) as an efficient $\mathrm{OH}$ source. No seed aerosol was used. The smog chamber is placed inside a temperature-controlled wooden enclosure kept at approximately $20^{\circ} \mathrm{C}$, slightly below ambient temperature outside this enclosure $\left(24-30^{\circ} \mathrm{C}\right)$.

Initially, the chamber was cleaned by flushing with ozone for 3-5 $\mathrm{h}$ and then with purified air (flow rate approximately $1501 \mathrm{~min}^{-1}$ ) for at least $24 \mathrm{~h}$. During experiments, the chamber was first humidified to a relative humidity of 5-10\% before introducing first ozone and then $\beta$-caryophyllene (>98.5\%, Fluka). Ozone generation is described by Paulsen et al. (2005); the initial concentration of ozone was $300 \mathrm{ppb}$. In experiments a and $\mathrm{b}, 0.22 \mathrm{ml}$ 2-butanol (corresponding to $\sim 2 \mathrm{ppm}$ ) was added by placing it in a glass sampling bulb and letting it evaporate by heating to $80^{\circ} \mathrm{C}$. The vapor was then flushed into the chamber with purified air. $6.3 \mu \mathrm{l} \beta$-caryophyllene was added in the same way, resulting in an initial concentration of $25 \mathrm{ppb}$. After injection of $\beta$-caryophyllene, measurements were carried out for up to $30 \mathrm{~h}$.

In experiments $\mathrm{f}-\mathrm{l}$, solar light was simulated with four xenon arc lamps (total $16 \mathrm{~kW}$ rated power), which were turned on at the same time as $\beta$-caryophyllene was injected. In spite of active cooling in the wooden enclosure, this typically caused the smog chamber temperature to rise to 
Table 1. Summary of all experiments. Four types of experiments have been carried out: dark ozonolysis with $\mathrm{OH}$ scavenger (2butanol); dark ozonolysis (without $\mathrm{OH}$ scavenger); lighted ozonolysis; lighted ozonolysis with $\mathrm{HONO}(\mathrm{OH}$-source). Also shown are the ranges of $D_{\text {dry,c }}$ and $S S_{\mathrm{c}}$ studied with the CF-CCNC, as well as the ambient temperature $\left(T_{\mathrm{am}}\right)$ and the maximum temperature in the $\mathrm{CF}-\mathrm{CCNC}\left(T_{\mathrm{CF}, \max }\right)$ for each individual experiment.

\begin{tabular}{|c|c|c|c|c|c|}
\hline & Date & $\begin{array}{l}D_{\text {dry,c }} \\
\mathrm{nm}\end{array}$ & $\begin{array}{l}S S_{\mathrm{c}}(\mathrm{CF}-\mathrm{CCNC}) \\
\%\end{array}$ & $\begin{array}{l}T_{\mathrm{am}} \\
{ }^{\circ} \mathrm{C}\end{array}$ & $\begin{array}{l}T_{\mathrm{CF}, \max } \\
{ }^{\circ} \mathrm{C}\end{array}$ \\
\hline \multicolumn{6}{|c|}{ 1: Dark ozonolysis $+\mathrm{OH}$ scavenger } \\
\hline $\mathrm{a}$ & 26 May & $122-163$ & $1.32-1.51$ & $28-30$ & $47-51$ \\
\hline $\mathrm{b}$ & 2 June & 114-190 & $1.32-1.51$ & $24-26$ & $42-48$ \\
\hline \multicolumn{6}{|c|}{ 2: Dark ozonolysis } \\
\hline $\mathrm{c}$ & 5 May & $47-222$ & $0.15-1.45$ & $24-26$ & $31-46$ \\
\hline d & 20 May & $112-129$ & 0.77 & $25-29$ & $39-43$ \\
\hline $\mathrm{e}$ & 12 June & $99-159$ & $1.32-1.66$ & $27-28$ & $48-50$ \\
\hline \multicolumn{6}{|c|}{ 3: Ozonolysis of $\beta$-caryophyllene + light } \\
\hline $\mathrm{f}$ & 22 May & $76-144$ & $0.29-0.77$ & $27-30$ & $34-41$ \\
\hline $\mathrm{g}$ & 8 June & $87-157$ & $0.25-0.77$ & $26-28$ & $32-40$ \\
\hline \multicolumn{6}{|c|}{ 4: Ozonolysis of $\beta$-caryophyllene $+\mathrm{HONO}+$ light } \\
\hline $\mathrm{h}$ & 4 June & $122-218$ & $0.17-1.74$ & $25-28$ & $31-51$ \\
\hline $\mathrm{i}$ & 10 June & $101-205$ & $0.17-0.60$ & $25-29$ & $32-38$ \\
\hline $\mathrm{j}$ & 15 June & $60-223$ & $0.17-1.51$ & $25-28$ & $33-48$ \\
\hline $\mathrm{k}$ & 17 June & $122-222$ & $0.17-0.77$ & $25-30$ & $35-39$ \\
\hline 1 & 19 June & $100-170$ & $0.45-1.89$ & $26-29$ & $38-51$ \\
\hline
\end{tabular}

approximately $25^{\circ} \mathrm{C}$. Temperature was constant for the entire duration of each experiment; the effect of this slight temperature increase on the formation and properties of SOA generated under exposure to light was considered negligible. Furthermore, in experiments $\mathrm{h}-\mathrm{l}, \mathrm{OH}$ was generated through photolysis of HONO, which was added continuously with a system designed according to Taira and Kanda (1990). Injection of HONO began at least 60 minutes before lights were turned on.

\subsection{Instruments}

Particle generation and growth was monitored with a Scanning Mobility Particle Sizer (SMPS) composed of a differential mobility analyzer (DMA, TSI 3071) and a condensation particle counter (CPC, TSI 3010). CCN activity of SOA was characterized with two CCN counters: One was a continuous-flow streamwise thermal-gradient $\mathrm{CCN}$ counter (CF-CCNC from DMT, CCNC-100, described by Roberts and Nenes, 2005 and Lance et al., 2006); the other was a static diffusion thermal-gradient $\mathrm{CCN}$ counter (SD-CCNC from University of Wyoming, Model 100B; described by Bilde and Svenningsson 2004; Snider et al., 2006, 2010; Svenningsson and Bilde, 2008).

The CCN counters were used to determine the sizedependent critical supersaturation $\left(S S_{\mathrm{c}}\right)$ for a known dry par- ticle size or the critical dry diameter $\left(D_{\text {dry,c }}\right)$ at a known supersaturation. Particles leaving the smog chamber were sent through a neutralizer and a DMA (custom-built, equivalent to TSI, model 3071) which operated with an aerosol to sheath flow ratio of 1:10 to ensure a narrow size distribution. The DMA selected a quasi-monodisperse sample flow with a known diameter $\left(D_{\text {dry }}\right)$, and varied in steps between different diameters. The flow leaving the DMA was then split between a CPC (TSI 3022A) and the two CCN counters. In the CFCCNC, $D_{\text {dry,c }}$ was determined for various constant values of SS. This was also done in the SD-CCNC, but during some experiments, $S S_{\mathrm{c}}$ was instead determined for known values of $D_{\text {dry }}$. Here supersaturation was varied in the range $0.05-2 \%$, and $S S_{\mathrm{c}}$ was determined for a given $D_{\mathrm{dry}}$.

The CPC (TSI 3022A) draws a flow of $0.31 \mathrm{~min}^{-1}$; the CFCCNC $0.51 \mathrm{~min}^{-1}$ and the SD-CCNC $31 \mathrm{~min}^{-1}$. The sheath flow in the DMA was $81 \mathrm{~min}^{-1}$. To obtain a sample to sheath flow ratio of 1:10, dilution of the sample flow after the DMA was necessary. This was done by sending the exhaust from the SD-CCNC $\left(31 \mathrm{~min}^{-1}\right)$ through a diffusion drier and a particle filter and adding it to the flow of $0.81 \mathrm{~min}^{-1}$ exiting the DMA. This dilution system was used during the fraction of each experiment when the SD-CCNC was running (up to eight hours in experiments lasting up to $30 \mathrm{~h}$ ). Turning off the SD-CCNC and disconnecting the dilution system did not change the fraction of activated particles, i.e. the ratio between the number concentration of activated particles (measured with the CCNC) and the total number concentration (measured with the CPC). It was therefore assumed that the chemical composition of the gas phase in the exhaust of the SD-CCNC was similar enough to the gas phase of the flow coming directly from the smog chamber, that dilution did not alter partitioning between particle and the gas phase in the aerosol flow.

To avoid a high level of doubly charged particles, the selected diameters were mainly chosen to be above the mode of the size distribution in the smog chamber. For all reported experiments, $D_{\mathrm{dry}, \mathrm{c}}$ as well as $S S_{\mathrm{c}}$ were determined by correcting for doubly charged particles and fitting the activated fraction as a function of dry particle diameter or supersaturation, respectively, to a sigmoidal function, similar to the approach of e.g. Prisle et al. (2008).

The CCN counters were calibrated using dry ammonium sulphate (AS) particles; measurements for the calibration curves were obtained both before and during the two months of smog chamber experiments.

The optical particle counter (OPC) of the CF-CCNC measures droplet size and can therefore describe growth kinetics of activating particles. For a given mass transfer coefficient of water, activated $\mathrm{CCN}$ will grow to droplets of similar diameter $\left(D_{\mathrm{OPC}}\right)$ if exposed to the same supersaturation. Some organic compounds can delay or even hinder growth kinetics (e.g. Nenes et al., 2001; Asa-Awuku and Nenes, 2007; Sjogren et al., 2007; Asa-Awuku et al., 2009). This effect is evaluated by comparing $D_{\mathrm{OPC}}$ of activated SOA to 


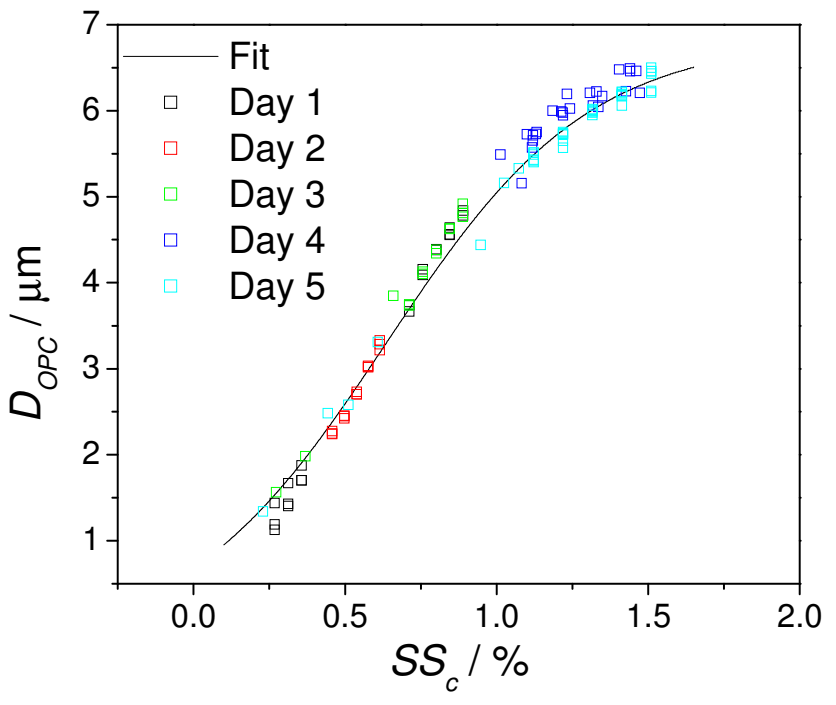

Fig. 1. Diameter of activated ammonium sulphate particles $\left(D_{\mathrm{OPC}}\right)$ as a function of critical supersaturation $\left(S S_{\mathrm{c}}\right)$. An empirical fit is also shown $\left(\mathrm{y}=1.24-2.79 \cdot \mathrm{x}+16.82 \cdot \mathrm{x}^{2}-13.70 \cdot \mathrm{x}^{3}+3.50 \cdot \mathrm{x}^{4}\right)$.

activating ammonium sulphate particles characterized at the same critical supersaturation and under identical conditions of instrument operation (similar to the approach of e.g. Engelhart et al., 2008; Asa-Awuku et al., 2009; Asa-Awuku et al., 2010). This technique is also referred to as Threshold Droplet Growth Analysis (TDGA). Since the CCN activity of ammonium sulphate in general is different from the $\mathrm{CCN}$ activity of SOA, the dry diameter of ammonium sulphate particles activating at a given supersaturation is different from the dry diameter of SOA activating at the same supersaturation, but if $\mathrm{CCN}$ experiments are carried out under identical conditions of instrument operation the activated droplets will grow to the same size when detected by the OPC. The aim was therefore not to report the actual size of the activated particles, but to detect any differences between activated SOA and ammonium sulfate particles. Time resolution for the CF-CCNC was $1 \mathrm{~s}$, but to increase accuracy dry particle size and supersaturation were kept constant for at least one minute, and $D_{\mathrm{OPC}}$ was averaged over this time period. Unweighted standard deviations were also determined in this way. $D_{\mathrm{OPC}}$ for ammonium sulphate particles at different supersaturations obtained during calibration measurements on different days are shown in Fig. 1.

Special attention was given to the concentration of $\mathrm{CCN}$ in the CF-CCNC to prevent vapor depletion affecting the size of activated droplets (Lathem and Nenes, 2011; Raatikainen et al., 2012). In all smog chamber experiments, the number concentration of $\mathrm{CCN}$ was below $2500 \mathrm{~cm}^{-3}$, which does not significantly influence the level of supersaturation in the instrument or activated droplet size (Lathem and Nenes, 2011).

During some parts of the experiments, a thermodenuder (TD) consisting of a heater and an activated charcoal denuder
(Burtscher et al., 2001) was inserted directly outside the smog chamber (before the particles entered the neutralizer and the DMA). The temperature of the TD was either ambient temperature (in the range $24-30^{\circ} \mathrm{C}$ ), $35^{\circ} \mathrm{C}$ or $50^{\circ} \mathrm{C}$. The heated section of the TD had an inner diameter of $2 \mathrm{~cm}$ and a length of $50 \mathrm{~cm}$. The flow through the TD was $0.81 \mathrm{~min}^{-1}$ in all experiments, corresponding to a residence time in the heated section of $6.2 \mathrm{~s}$. This is slightly shorter than the residence time in the growth chamber of the CF-CCNC $(\sim 8 \mathrm{~s})$. The importance of a sufficiently long residence time to establish equilibrium between the gas and particle phases for quantitative studies of evaporation rates has been addressed by e.g. Riipinen et al. (2010). In the present study, however, the TD was used to study if a qualitative correlation between volatility and CCN activity could be determined for SOA.

Equal aerosol sample temperatures at the inlet of the CCNC instruments were crucial for a valid comparison of the measurements with and without TD. The tubes between the TD and the two CCNC's were of equal length and we assume the two inlet temperatures to be the same. The temperature of the aerosol flow was measured at the inlet of the $\mathrm{CF}-\mathrm{CCNC}$ and was found to be independent on TD temperature and flow type (i.e. TD inline or bypassed). This indicates that the temperature of the aerosol flow entering the SD-CCNC and CF-CCNC after passing through the TD had same temperature as an aerosol flow bypassing the TD.

Particles are lost in a TD due to different processes, e.g. Brownian diffusion, and sedimentation (Burtscher et al., 2001). The magnitude of these losses depends on flow rate and particle size and was estimated by comparing the particle number concentration when the TD was bypassed to the number concentration when particles went through the TD without any heating. This transmission was $80-90 \%$ in the presented experiments (not including effects of thermophoresis).

\section{Results and discussion}

Results from SMPS scans from individual experiments are shown in Fig. 2. Fig. 2a shows the total number concentration as a function of time after initial injection of $\beta$ caryophyllene, and Fig. $2 \mathrm{~b}$ shows the mean dry particle diameter as a function of time after injection of $\beta$-caryophyllene. In the four types of experiments, $\mathrm{OH}$ levels gradually increased (see Table 1). OH concentration was minimal during experiments a and b, i.e. with $\mathrm{OH}$ scavenger. During experiments without an $\mathrm{OH}$ scavenger (experiments $\mathrm{c}-\mathrm{e}$ ), $\mathrm{OH}$ was generated during ozonolysis, and $\mathrm{OH}$ levels were higher during experiments with lights on, either with or without the addition of an $\mathrm{OH}$ source (i.e. photolysis of $\mathrm{HONO}$ ).

After nucleation, the total number concentration decreased as a function of time due to coagulation and wall losses in the smog chamber. Similar total number concentrations were obtained during all four types of experiments (Fig. 2a), but 

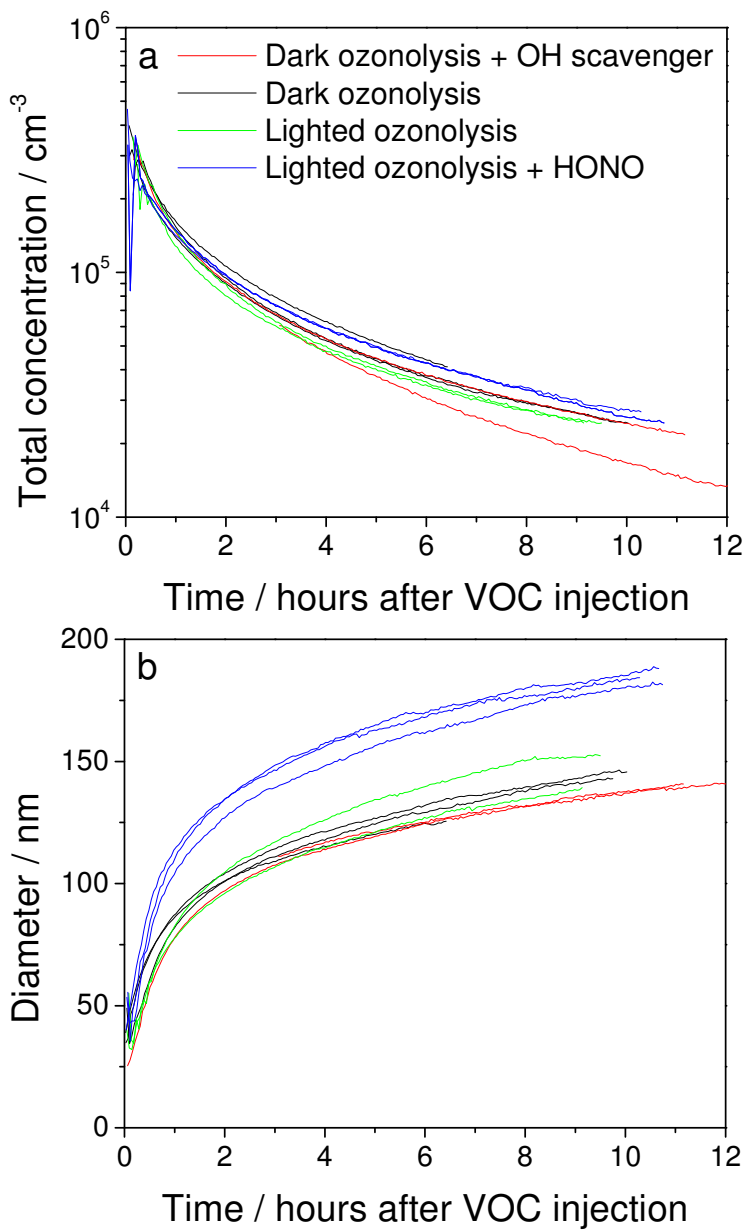

Fig. 2. Total number concentration (a) and mean diameter (b) of particles produced in individual experiments (the four types of experiments are summarized in Table 1) as a function of time. Note that data were not corrected for losses to the smog chamber walls.

experiments carried out with lights on and the addition of HONO in general resulted in larger particles (Fig. 2b).

\subsection{CCN activity of particles generated in dark experiments}

Two types of experiments were carried out with lights off (experiments a-e, see Table 1). In two of these experiments, 2-butanol was added to act as an $\mathrm{OH}$ scavenger (experiments a and b). Figure 3 a shows the critical diameter $D_{\text {dry,c }}$ of SOA (at $0.60-1.51 \%$ supersaturation) for these two types of experiments. To ease comparison between results from different supersaturations, $\kappa_{\mathrm{CCN}}$ is shown in Fig. $3 b$. All CCN measurements displayed in Fig. 3 were performed with the CFCCNC.

In experiments with an $\mathrm{OH}$ scavenger (experiments a and b), the generated particles did not activate at supersaturations below $1.3 \%$ for the several hours after nucleation. Therefore, $D_{\text {dry,c }}$ was only determined at $S S=1.32$ and $1.51 \%$, shown
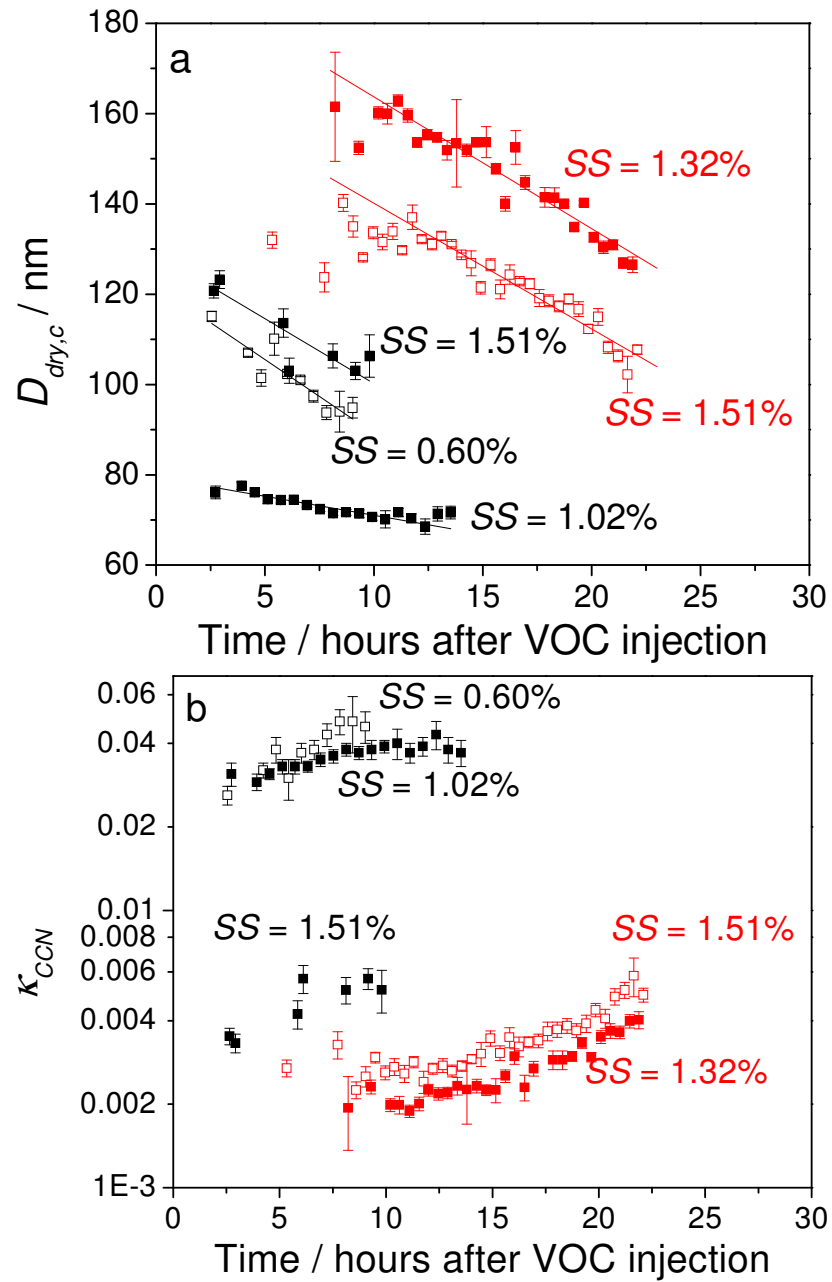

Fig. 3. Critical diameter $D_{\text {dry,c }}$ (a) and $\kappa_{\mathrm{CCN}}$ (b) of SOA formed from dark ozonolysis of $\beta$-caryophyllene measured with the $\mathrm{CF}$ CCNC, either without (black points/lines) or with (red points/lines) the addition of an $\mathrm{OH}$ scavenger (2-butanol). Data are shown for different supersaturations in the range $0.60-1.51 \%$. For each supersaturation, a straight line (see Table 2 ) is fitted to $D_{\text {dry,c }}$.

in Fig. 3. $\kappa_{\mathrm{CCN}}$ was in the range $0.001-0.005$. For both supersaturations, a temporal trend was observed: the CCN activity decreased linearly with time (from to $163 \mathrm{~nm}$ to $124 \mathrm{~nm}$ over $17 \mathrm{~h}$, with a rate of $3.0 \pm 0.2 \mathrm{~nm} \mathrm{~h}^{-1}$ for $S S=1.32 \%$, and from $140 \mathrm{~nm}$ to $102 \mathrm{~nm}$ with a rate of $2.8 \pm 0.14 \mathrm{~nm} \mathrm{~h}^{-1}$ for $S S=1.51 \%$, see Table 2). This is in quantitative agreement with the findings of Asa-Awuku et al. (2009), who at $S S=1.02 \%$ observed a linear decrease in $D_{\text {dry,c }}$ in the range $70-90 \mathrm{~nm}$ of $3.0 \mathrm{~nm} \mathrm{~h}^{-1}$, and at $S S=0.61 \%$ observed a linear decrease in the range $115-130 \mathrm{~nm}$ of $2.0 \mathrm{~nm} \mathrm{~h}^{-1}$ (corresponding to $\kappa_{\mathrm{CCN}}$ in the range $0.017-0.040$ ) over a period of approximately $10 \mathrm{~h}$ for particles generated in absence of OH. Huff-Hartz et al. (2005) reported a $D_{\mathrm{dry}, \mathrm{c}}=152 \pm 26 \mathrm{~nm}$ at $S S=1 \%$ of particles generated from ozonolysis of $\beta$ caryophyllene in the presence of 2-butanol. This corresponds 

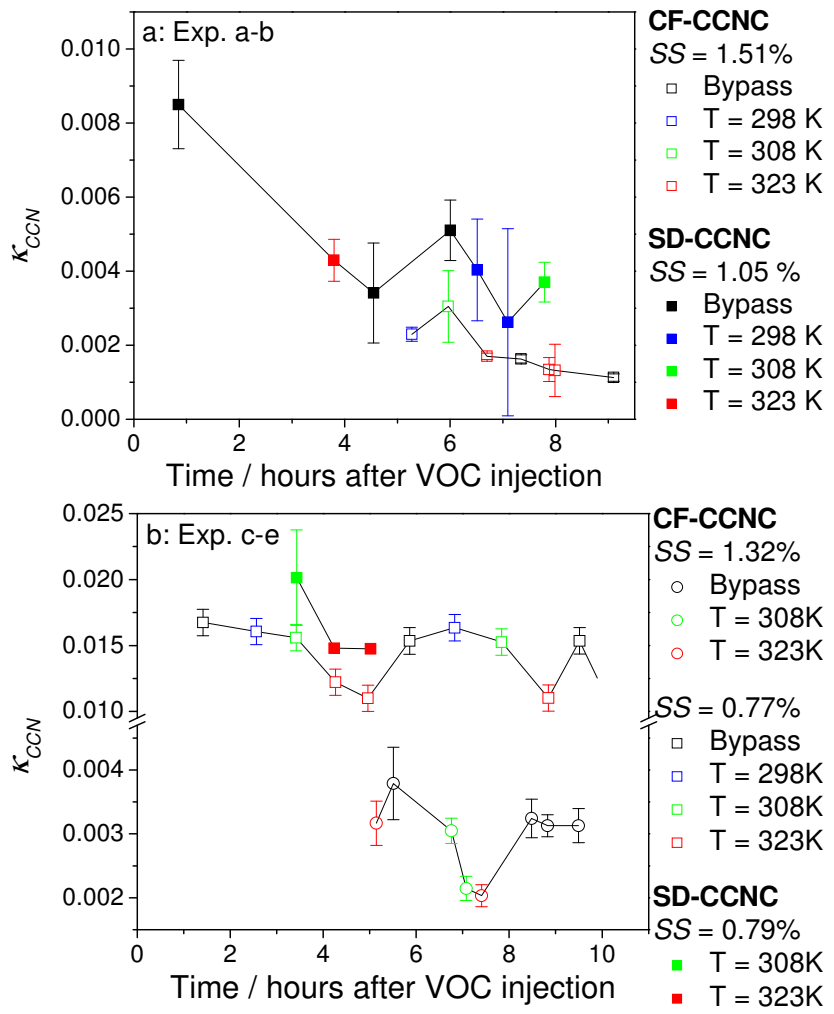

Fig. 4. Single hygroscopicity parameters $\left(\kappa_{\mathrm{CCN}}\right)$ for SOA from dark ozonolysis of $\beta$-caryophyllene with (a) or without (b) the addition of an $\mathrm{OH}$ scavenger (2-butanol). For some time during each experiment, the aerosol particles were sent through a thermodenuder, operated at three different temperatures. Points are connected to aid visual inspection.

to $\kappa_{\mathrm{CCN}}=0.004$, which is less $\mathrm{CCN}$ active than SOA studied by Asa-Awuku et al. (2009), but in good agreement with the findings of the present study.

Particles generated in the presence of $\mathrm{OH}$ (experiments c-e) were significantly more CCN active and also showed an increase in $\kappa_{\mathrm{CCN}}$ as a function of time. In the present study, the CCN activity was studied at three different supersaturations: At $S S=0.60 \%, D_{\text {dry,c }}$ decreased from $115 \mathrm{~nm}$ to $94 \mathrm{~nm}\left(\kappa_{\mathrm{CCN}}=0.029-0.043\right)$ over $6.5 \mathrm{~h}$ corresponding to $3.3 \pm 0.3 \mathrm{~nm} \mathrm{~h}^{-1}$ and at $S S=1.02 \%, D_{\text {dry,c }}$ decreased from $78 \mathrm{~nm}$ to $69 \mathrm{~nm}\left(\kappa_{\mathrm{CCN}}=0.026-0.048\right)$ over $10 \mathrm{~h}$, corresponding to $0.85 \pm 0.9 \mathrm{~nm} \mathrm{~h}^{-1}$ (see also Table 2). Asa-Awuku et al. (2009) determined $D_{\mathrm{dry}, \mathrm{c}}$ at the same two supersaturations and observed a $D_{\mathrm{dry}, \mathrm{c}}$ in the range $105-130 \mathrm{~nm}$ (corresponding to $\left.\kappa_{\mathrm{CCN}}=0.018-0.038\right)$ and a decrease of $2.6 \mathrm{~nm} \mathrm{~h}^{-1}$ over approximately $10 \mathrm{~h}$ for $S S=0.61 \%$; for $S S=1.02 \%$ $D_{\text {dry,c }}$ was in the range $65-95 \mathrm{~nm}\left(\kappa_{\mathrm{CCN}}=0.010-0.050\right)$, corresponding to a decrease of $2.8 \mathrm{~nm} \mathrm{~h}^{-1}$. In the present study, $D_{\text {dry,c }}$ is within the same range but slightly lower than reported by Asa-Awuku et al. (2009).

In the present study, $D_{\text {dry,c }}$ was also determined at $S S=1.51 \%$ and observed to decrease from $123 \mathrm{~nm}$ to
Table 2. Effect of ageing on $D_{\mathrm{dry}, \mathrm{c}}$ at various supersaturations in the four types of smog chamber experiments.

\begin{tabular}{|c|c|c|c|}
\hline \multicolumn{2}{|r|}{ Present study } & \multicolumn{2}{|c|}{ Asa-Awuku et al. (2009) } \\
\hline$S S / \%$ & d $D_{\text {dry,c }} / \mathrm{d}$ time & $S S / \%$ & d $D_{\text {dry,c }} / \mathrm{d}$ time \\
\hline \multicolumn{4}{|c|}{ 1: Dark ozonolysis $+\mathrm{OH}$ scavenger } \\
\hline 1.51 & $2.8 \pm 0.16 \mathrm{~nm} \mathrm{~h}^{-1}$ & - & - \\
\hline 1.32 & $3.0 \pm 0.2 \mathrm{~nm} \mathrm{~h}^{-1}$ & - & - \\
\hline- & - & 1.02 & $3.0 \mathrm{~nm} \mathrm{~h}^{-1}$ \\
\hline- & - & 0.61 & $2.0 \mathrm{~nm} \mathrm{~h}^{-1}$ \\
\hline \multicolumn{4}{|c|}{ 2: Dark ozonolysis } \\
\hline 1.51 & $2.9 \pm 0.5 \mathrm{~nm} \mathrm{~h}^{-1}$ & - & - \\
\hline 1.02 & $0.85 \pm 0.09 \mathrm{~nm} \mathrm{~h}^{-1}$ & 1.02 & $2.8 \mathrm{nmh}^{-1}$ \\
\hline 0.60 & $3.3 \pm 0.3 \mathrm{~nm} \mathrm{~h}^{-1}$ & 0.61 & $2.6 \mathrm{~nm} \mathrm{~h}^{-1}$ \\
\hline \multicolumn{4}{|c|}{ 3: Ozonolysis of $\beta$-caryophyllene + light } \\
\hline 0.35 & $0.54 \pm 0.2 \mathrm{~nm} \mathrm{~h}^{-1}$ & - & - \\
\hline 0.29 & $0.59 \pm 0.14 \mathrm{~nm} \mathrm{~h}^{-1}$ & - & - \\
\hline 0.25 & $1.16 \pm 0.3 \mathrm{~nm} \mathrm{~h}^{-1}$ & - & - \\
\hline \multicolumn{4}{|c|}{ 4: Ozonolysis of $\beta$-caryophyllene $+\mathrm{HONO}+$ light } \\
\hline 0.29 & $0.69 \pm 0.12 \mathrm{nmh}^{-1}$ & - & - \\
\hline 0.23 & $0.47 \pm 0.2 \mathrm{~nm} \mathrm{~h}^{-1}$ & - & - \\
\hline 0.20 & $0.23 \pm 0.3 \mathrm{~nm} \mathrm{~h}^{-1}$ & - & - \\
\hline 0.17 & $0.78 \pm 0.4 \mathrm{~nm} \mathrm{~h}^{-1}$ & - & - \\
\hline
\end{tabular}

$103 \mathrm{~nm}$ over $7 \mathrm{~h}$, corresponding to $2.9 \pm 0.5 \mathrm{~nm} \mathrm{~h}^{-1}$. However, it is notable that $D_{\mathrm{dry}, \mathrm{c}}$ is larger at $S S=1.51 \%$, than at $S S=0.60 \%$ and $1.02 \%$. This is more clearly seen in Fig. 3b, showing $\kappa_{\mathrm{CCN}}$ in the range $0.003-0.006$ obtained at $S S=1.51 \%$, which is approximately a factor of ten smaller than the values obtained at $0.60 \%$ and $1.02 \%$. The reason for this may be related to effects of the relatively high temperature in the CF-CCNC, which is discussed further in Sect. 4.3.

Tang et al. (2012) examined SOA from low initial concentrations of $\beta$-caryophyllene (5-20 ppb) and did not detect any temporal trends in the $\mathrm{CCN}$ activity of SOA generated in the absence of an $\mathrm{OH}$ scavenger. They consistently observed high $\kappa_{\mathrm{CCN}}$ values $(0.13-0.25)$, ascribed to the low precursor concentrations resulting in SOA mainly composed of highly oxidized compounds of high hygroscopicity and CCN activity. This is consistent with the conclusions of Duplissy et al. (2008).

The differences between results of Tang et al. (2012) and this study (and Asa-Awuku et al. (2009)) are surprising and interesting and should be investigated further.

The CCN activity of particles generated with no lights on was related to volatility through the use of a TD. The effect for particles from experiments with the addition of an $\mathrm{OH}$ scavenger (experiments a and b) is seen in Fig. 4a: No relation between $\mathrm{CCN}$ activity and volatility was detected as no systematic change beyond experimental uncertainty 
(as represented by the error bars in Fig. 4a) was observed. However, $\kappa_{\mathrm{CCN}}$ values from the SD-CCNC were consistently higher than the data reported from the CF-CCNC. This could be caused by the two instruments operating at different supersaturations or due to effects of temperature, as suggested by Asa-Awuku et al. (2009).

The effect of the TD on $\kappa_{\mathrm{CCN}}$ for particles from experiments without $\mathrm{OH}$ scavenger (experiments c-e) is illustrated in Fig. 4b. After passing through the TD set to a temperature of 35 or $50^{\circ} \mathrm{C}$ (corresponding to 308 or $323 \mathrm{~K}$, respectively), the $\mathrm{CCN}$ activity of the particles was lower, indicating that the volatile components evaporating from the surface in the TD were also the more hygroscopic. This is in agreement with previous observations for $\beta$-caryophyllene (Asa-Awuku et al., 2009; Alfarra et al., 2012; Tang et al., 2012).

Only a small number of data points are available from the SD-CCNC. Therefore no firm conclusions can be drawn, but the SD-CCNC seemed to measure a slightly higher $\mathrm{CCN}$ activity than the CF-CCNC. Based on the effects of the TD on the measurements from the CF-CCNC, this was also expected since the CF-CCNC operated at a higher temperature: At $S S=0.77 \%$ and ambient temperatures in the range $25-29^{\circ} \mathrm{C}(298-302 \mathrm{~K})$, the maximum temperature in the CF$\mathrm{CCNC}$ was up to $43^{\circ} \mathrm{C}(316 \mathrm{~K})$, whereas during the experiments discussed in Fig. $4 \mathrm{~b}$ the SD-CCNC operated at $21-27^{\circ} \mathrm{C}(294-300 \mathrm{~K})$.

The difference in the post-TD CCN activity indicates that the physical properties of the products from pure ozonolysis are different from those of SOA produced in the presence of $\mathrm{OH}$. Either reactions without $\mathrm{OH}$ result in less variability in volatility and hygroscopicity, or else there is no connection between evaporative properties and $\mathrm{CCN}$ activity for the components generated from pure ozonolysis (i.e. when $\mathrm{OH}$ is scavenged). This may be linked to the finding by Tang et al. (2012) who related the presence of $\mathrm{OH}$ during oxidation to the formation of particles of higher oxidation state and increased hygroscopicity.

\subsection{CCN activity of particles generated in light experiments}

In experiments $\mathrm{f}-\mathrm{l}$, ozonolysis of $\beta$-caryophyllene was carried out with lights turned on, either with or without the addition of HONO. SOA produced in this way was substantially more $\mathrm{CCN}$ active than SOA produced in experiments a-e (see Fig. 5). Figure 5a shows $D_{\text {dry,c }}$ determined with the CF-CCNC as a function of time in experiments $f$ and $\mathrm{g}$ (without HONO). For the three lowest supersaturations, the temporal trends were consistent with observations from the dark experiments: Linear decreases in $D_{\text {dry,c }}$ as functions of time were observed for supersaturations in the range of $0.25-0.35 \%$ (see Table 2). $D_{\text {dry,c }}$ measured at $S S=0.77 \%$ also decreased with time, although a linear trend was not obvious. Figure $5 \mathrm{~b}$ shows $\kappa_{\mathrm{CCN}}$ from experiments $\mathrm{f}$ and $\mathrm{g}$; to make it more readable, error bars in $\kappa_{\mathrm{CCN}}$ are not shown.
However, experimental errors were up to $30 \%$, (similar to the errors in $\kappa_{\mathrm{CCN}}$ shown in Fig. $3 b$ ).

Figure 5 c shows $D_{\text {dry,c }}$ as a function of time during experiments h-1 (lighted ozonolysis with production of $\mathrm{OH}$ from photolysis of HONO). For three $S S(0.29,0.23$, and $0.17 \%)$, slight decreases in $D_{\text {dry,c }}$ with time were observed (see Table 2), of the same order of magnitude as the decreases observed for SOA generated in experiments $f$ and g. At the fourth $S S(0.20 \%), D_{\mathrm{dry}, \mathrm{c}}$ did not change with time. Figure $5 \mathrm{~d}$ shows $\kappa_{\mathrm{CCN}}$ from experiments h-l (experimental errors up to $30 \%$ not displayed). Within this relatively limited range of supersaturations (between 0.17 and $0.29 \%$ ), only a weak dependency of $\kappa_{\mathrm{CCN}}$ on $S S$ was observed, as the average of $\kappa_{\mathrm{CCN}}$ determined at $S S=0.17 \%$ was approximately $20 \%$ lower than the average of $\kappa_{\mathrm{CCN}}$ measured at the three higher $S S$ ( 0.059 versus 0.073 , respectively).

Alfarra et al. (2012) studied SOA generated from photooxidation of $\beta$-caryophyllene in the presence of $\mathrm{NO}_{\mathrm{x}}$ and determined $\kappa_{\mathrm{GF}}$ (using growth factors at $90 \%$ relative humidity) as well as $\kappa_{\mathrm{CCN}}$. They discovered no size dependency in hygroscopicity and little or no difference between the growth factors of individual particles at a measured dry size (between 50 and $300 \mathrm{~nm}$ ). Growth factors of a given size tended to increase slightly during an experiment, although not beyond experimental uncertainty, resulting in $\kappa_{\mathrm{GF}}$ in the range $0-0.03$ and $\kappa_{\mathrm{CCN}}$ in the range $0-0.02$. Alfarra et al. (2012) carried out photo-oxidation at two different initial $\beta$-caryophyllene concentrations, 50 and $250 \mathrm{ppb}$, but did not observe any influence of precursor concentration on hygroscopicity, which is in contrast with the findings for SOA generated from photo-oxidation of $\alpha$-pinene by Duplissy et al. (2008). Considering that the formation and subsequent ageing of the SOA investigated by Alfarra et al. (2012) was only observed for up to $6 \mathrm{~h}$, the magnitudes of $\kappa_{\mathrm{GF}}$ are in reasonable agreement with the measurements at $0.77 \%$ in experiment $\mathrm{g}$ in the present study (Fig. 5b), which were also obtained within the first $6 \mathrm{~h}$ after initial nucleation.

Figure 6 shows the effect of sending particles through a TD prior to size selection and characterization in the two $\mathrm{CCN}$ counters. $\kappa_{\mathrm{CCN}}$ consistently increased with time independently of the TD temperature, and $\kappa_{\mathrm{CCN}}$ values from the CF-CCNC agreed well with values from the SD-CCNC. This is different from dark ozonolysis experiments, where particles were slightly less $\mathrm{CCN}$ active after passing them through the TD (see Fig. 4). Precluding effects of temporal variations in volatility, these observations indicate that SOA generated under light exposure is less volatile than SOA generated without light exposure, or at least that the compounds contributing to the CCN activity are not highly volatile in particles generated under exposure to light.

Figure 7 shows the effect of sending particles generated with lights on and the addition of HONO through a TD. All CF-CCNC data shown in Fig. 7 were obtained from three different experiments at $S S=0.29 \%$. The SD-CCNC data were obtained at a constant $D_{\text {dry }}(100$ and $150 \mathrm{~nm})$ by varying $S S$, 

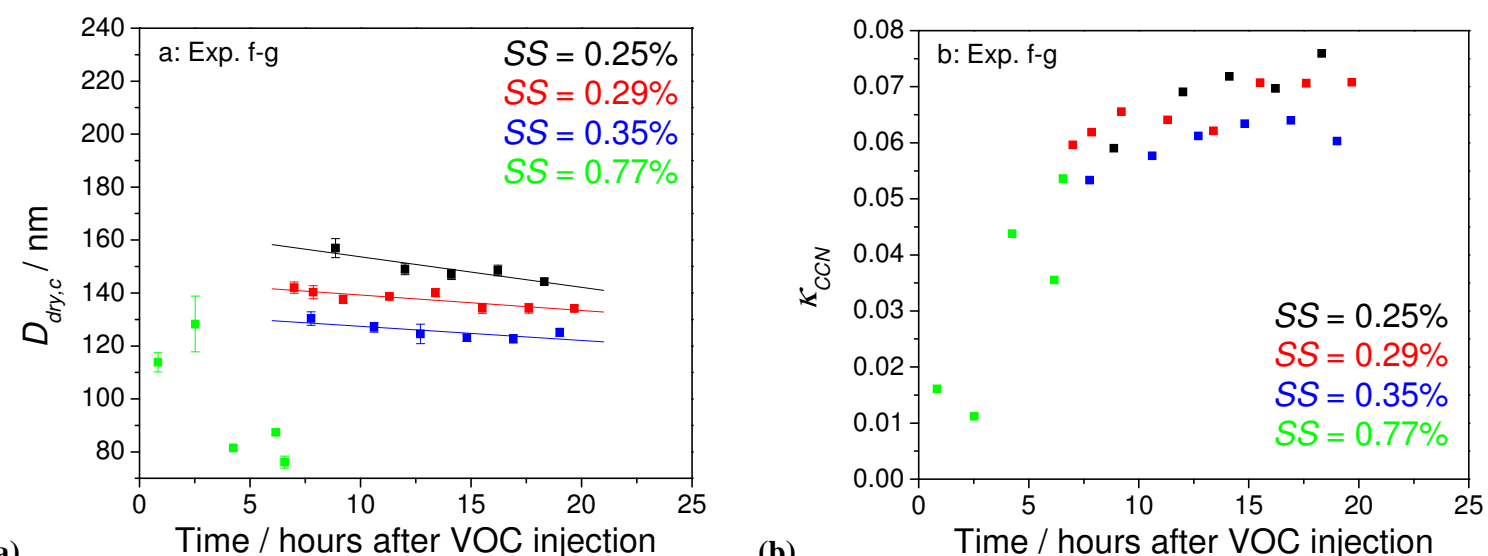

(a)

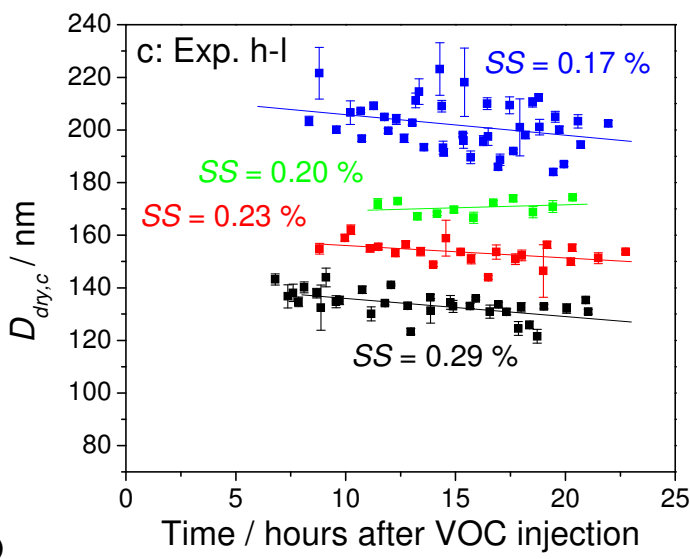

(b)

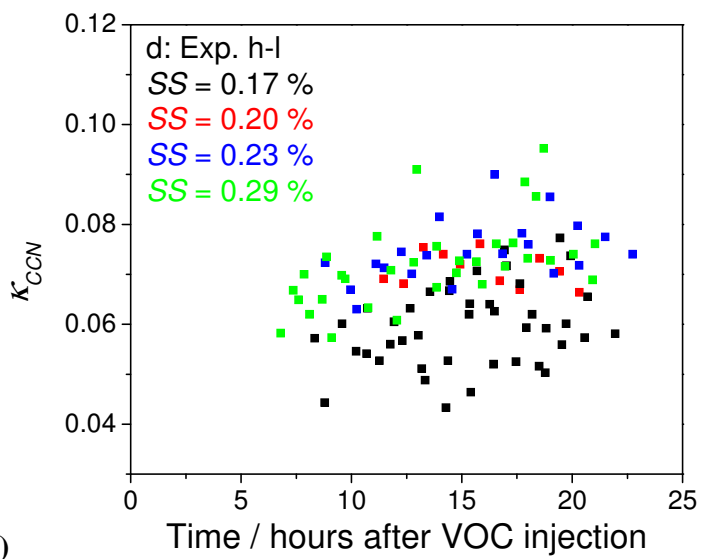

Fig. 5. Critical diameter $\left(D_{\mathrm{dry}, \mathrm{c}}\right)$ and $\kappa_{\mathrm{CCN}}$ of SOA measured with the CF-CCNC for experiments with lights on (a and b) and with lights on and the addition of HONO (c and d). Data are shown for different supersaturations in the range $0.17-0.77 \%$. Experimental uncertainties in determining $\kappa_{\mathrm{CCN}}$ were up to $30 \%$ (error bars not shown). Straight lines were fitted to $D_{\text {dry,c }}$ (see Table 2).

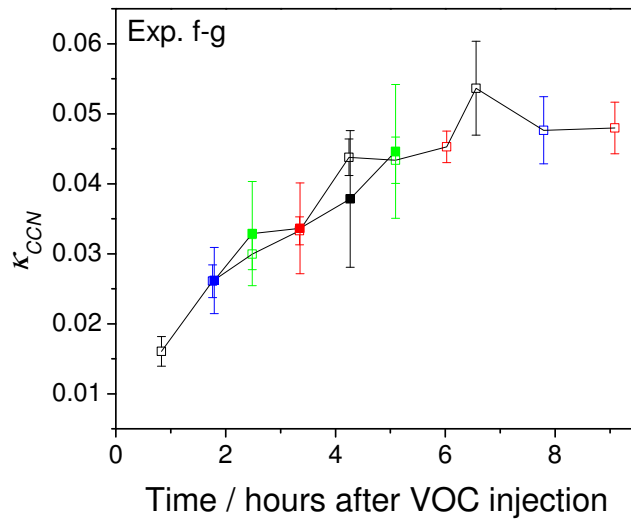

Fig. 6. Single hygroscopicity parameters $\left(\kappa_{\mathrm{CCN}}\right)$ of SOA from lighted ozonolysis of $\beta$-caryophyllene. For some time during each experiment, the aerosol particles were sent through a thermodenuder, operated at three different temperatures. Points are connected to aid visual inspection. resulting in $S S_{\mathrm{c}}$ in the range $0.28-0.45 \%$. As was the case in Fig. 6, an increase in $\kappa_{\mathrm{CCN}}$ was observed for measurements from both the CF-CCNC and the SD-CCNC, but no effect was observed from the TD. $\kappa_{\mathrm{CCN}}$ measured with the $\mathrm{CF}$ $\mathrm{CCNC}$ agreed with $\kappa_{\mathrm{CCN}}$ measured at $150 \mathrm{~nm}$ with the SDCCNC. The $\kappa_{\mathrm{CCN}}$ values obtained with the SD-CCNC for $100 \mathrm{~nm}$ particles were, however, significantly higher. These data are associated with large uncertainties, but the difference may indicate a dependency of $\kappa_{\mathrm{CCN}}$ on $S S$ (or $D_{\mathrm{dry}, \mathrm{c}}$ ).

\subsection{Temperature effects}

The CCN activity of SOA from oxidation of $\beta$-caryophyllene was characterized at several different supersaturations, and, as seen above, $\kappa_{\mathrm{CCN}}$ was not constant for all supersaturations. This is also shown in Fig. 8, which compiles data (without using the TD) from all smog chamber experiments. To guide the eye, a power function has been fit to the data. The trend and the scattering of data around the empirical fit was to some extent related to the effects of chemical ageing: When the CCN counters were operated at a constant $S S$ for extended periods of time, an increase of $\kappa_{\mathrm{CCN}}$ was 


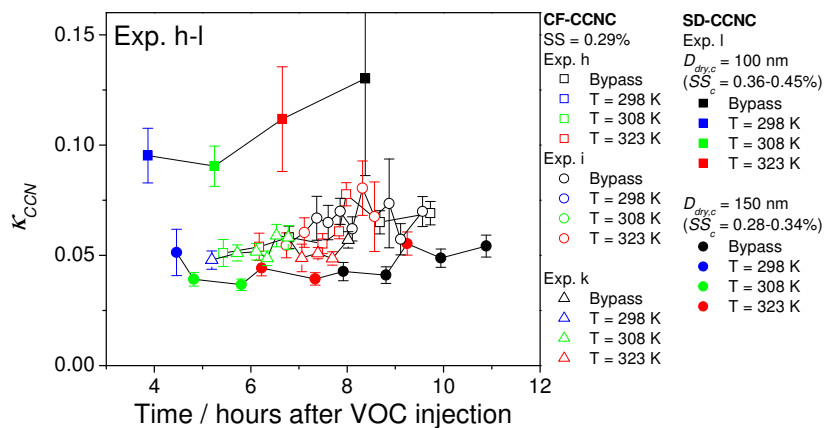

Fig. 7. Single hygroscopicity parameter $\left(\kappa_{\mathrm{CCN}}\right)$ of SOA formed from ozonolysis of $\beta$-caryophyllene with the addition of $\mathrm{OH}$ (generated from photolysis of HONO). For some time during each experiment, the aerosol particles were sent through a thermodenuder operated at three different temperatures. Points are connected to aid visual inspection.

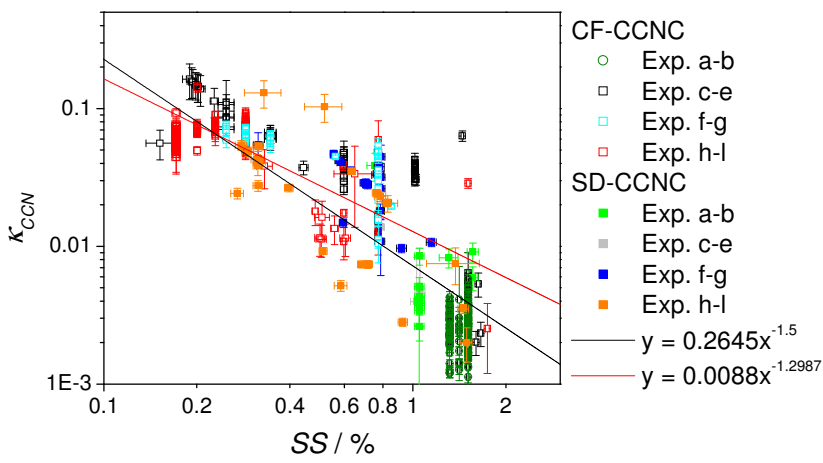

Fig. 8. Single hygroscopicity parameter $\left(\kappa_{\mathrm{CCN}}\right)$ of SOA as a function of supersaturation for the four different types of experiments described in Table 1. To guide the eye, all available data are compared to two power law fits (empirical fits), one of which is forced with an exponent of -1.5 .

observed (see Figs. 3 and 5). Also, measurements at high values $(>1 \%)$ were mainly performed during the first few hours after $\beta$-caryophyllene injection. Since chemical ageing resulted in a significant increase in $\mathrm{CCN}$ activity, it is also expected that the particles studied early in the experiment at high supersaturations were also the least $\mathrm{CCN}$ active. However, as clearly demonstrated in e.g. Fig. 3b, even for simultaneous measurements at different supersaturations, variations in $\kappa_{\mathrm{CCN}}$ are observed, and other explanations must exist.

The dependence of $\kappa_{\mathrm{CCN}}$ on $S S$ may in part reflect the problems discussed by Petters and Kreidenweis (2007) of using a constant $\kappa$ value for a wide range of concentrations: A single value of $\kappa$ may not accurately characterize the water uptake of the aerosol for the whole atmospherically relevant range of humidity from sub- to supersaturation (Petters and Kreidenweis et al., 2007). $\kappa$-theory assumes that $\kappa_{\mathrm{CCN}}$ accounts for water activity, but deviations from ideality may

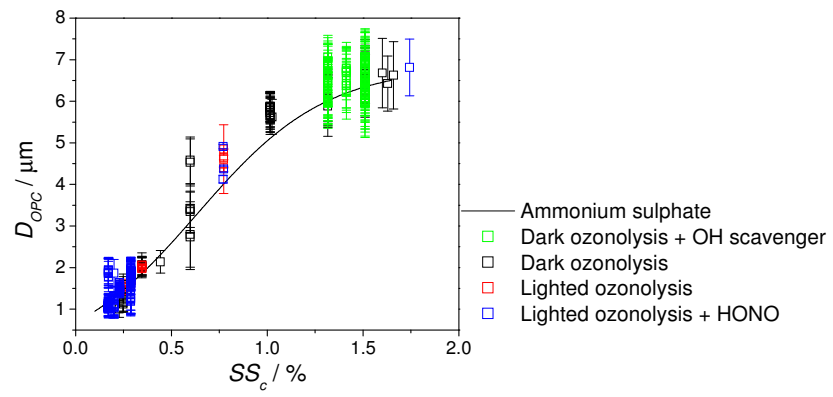

Fig. 9. Diameter of activated particles $\left(D_{\mathrm{OPC}}\right)$ as a function of critical supersaturation $\left(S S_{\mathrm{c}}\right)$. The individual points from smog chamber experiments are compared to the curve obtained from ammonium sulphate calibrations (see Fig. 1).

vary significantly with dilution. For example, the concentration dependency of water activity for a number of atmospherically relevant organic-inorganic mixtures at concentration ranges relevant at $\mathrm{CCN}$ activation are listed in Frosch et al., 2011b. Another possible explanation for the $S S$ dependency of $\kappa_{\mathrm{CCN}}$ is based on the relation between $S S$ and temperature in the CF-CCNC: For large SS, CF-CCNC operates at a high temperature (up to $51^{\circ} \mathrm{C}$, see Table 1) so that material may partially volatilize inside the instrument, leaving a residual that is less $\mathrm{CCN}$ active (assuming a previous correlation between volatility and $\mathrm{CCN}$ activity, as discussed by Asa-Awuku et al., 2009 and Tang et al., 2012). Furthermore, material evaporating from the particle surface inside the CF-CCNC decreases the particle diameter to a value lower than selected by the DMA, resulting in a higher $S S_{\mathrm{c}}$. Such an effect has for example been observed for particles composed of pure glutaric acid (Frosch et al., 2010). This effect of temperature on particle composition as well as on size is a likely explanation of the puzzling behavour observed in Fig. 3a: That at $S S=1.51 \%$, particles had a higher $D_{\text {dry,c }}$ than at $S S=0.60 \%$ and $1.02 \%$. However, if volatility was the only factor governing the change in $\kappa_{\mathrm{CCN}}$, measurements performed with the SD-CCNC should consistently result in higher $\kappa_{\mathrm{CCN}}$ than measurements performed with the CF-CCNC. This is the case only for particles generated in experiments a-e (without exposure to light). Therefore, a thorough study of volatility of SOA from $\beta$-caryophyllene oxidation would be helpful in understanding the observed values of $\kappa_{\mathrm{CCN}}$.

For particles generated under exposure to light, other explanations for the $S S$ dependency of $\kappa_{\mathrm{CCN}}$ are suggested: For example, it was implicitly assumed that the chemical composition of SOA is independent of particle size. However, heterogeneous chemical reactions may play a role in chemical ageing, and the rates and products of such reactions might depend on particle size. Also, surface activity of products formed under dark and lighted conditions may differ. The $\kappa_{\mathrm{CCN}}$ values in the present study were calculated using a constant surface tension equal to the surface tension of pure 


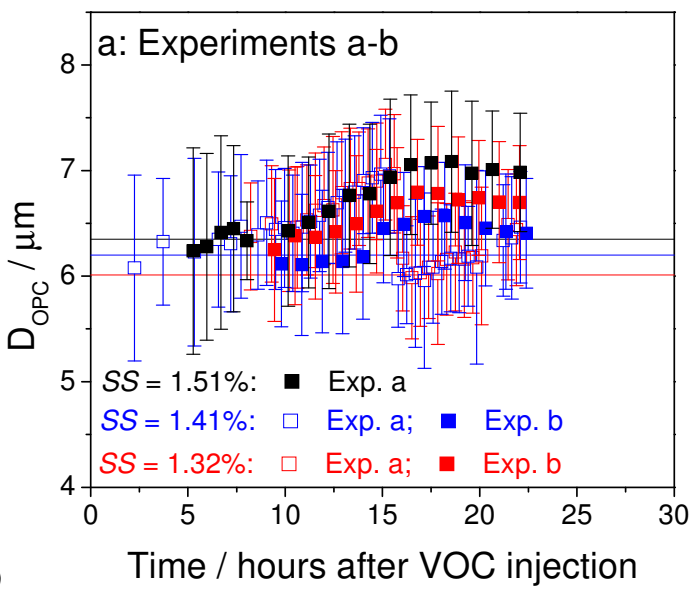

(a)

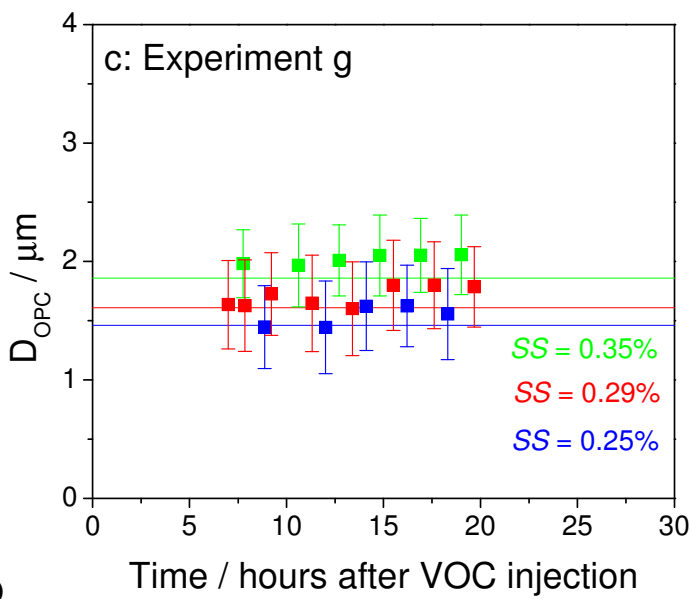

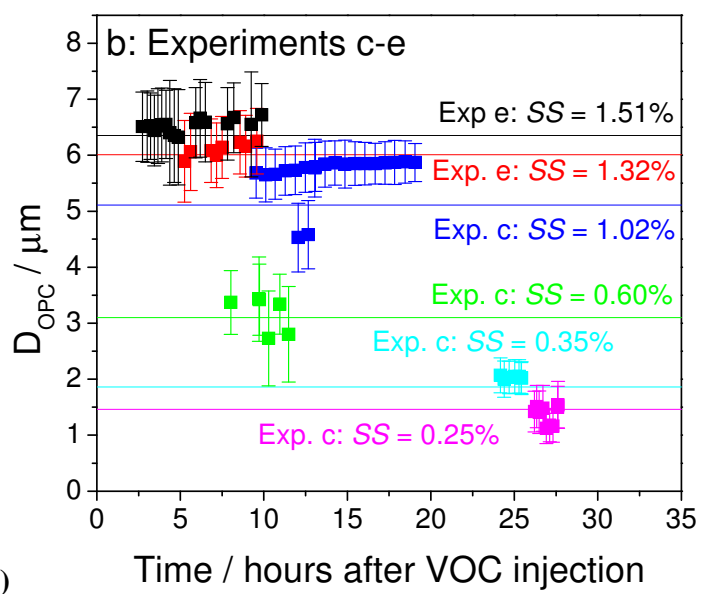

(b)

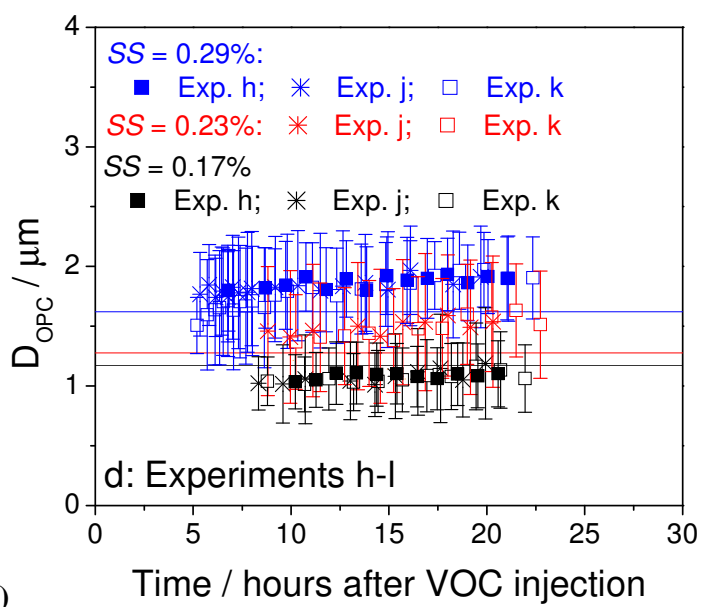

Fig. 10. Diameter of activated particles $\left(D_{\mathrm{OPC}}\right)$ as a function of time after injection of $\beta$-caryophyllene for different particle sizes, compared to $D_{\mathrm{OPC}}$ of activating ammonium sulphate particles with the same critical supersaturation (solid, horizontal lines). Data are separated into dark ozonolysis (a), dark ozonolysis with OH scavenger (b), lighted ozonolysis (c) and lighted ozonolysis with HONO (d).

water. However, using Köhler Theory Analysis (KTA) and filter sample extracts, Asa-Awuku et al. (2009) estimated that the hygroscopic fraction of SOA generated from ozonolysis of $\beta$-caryophyllene without exposure to light was surface active at activation conditions, resulting in $\sigma_{\mathrm{al}}=65.5 \pm 2 \mathrm{mN} \mathrm{m}$. Surface tension of products formed under lighted conditions has not yet been studied.

As shown by Li et al. (1998), Sorjamaa et al. (2004), and Prisle et al. (2008) it is important to account for a concentration dependence of surface tension and surfactant surface partitioning when calculating the CCN activity. Assuming a constant surface tension can lead to overestimation of the $\mathrm{CCN}$ activity (i.e. too high values of $\kappa_{\mathrm{CCN}}$ ) in particular for small particles and high critical supersaturations. Detailed modeling accounting for surfactant partitioning is outside the scope of this work, however it is not likely that a reduced surface tension can explain the behavior observed in Fig. 8.

\subsection{CCN activation kinetics}

Growth kinetics of SOA particles is explored in Fig. 9, where the wet diameter of activated particles, $D_{\mathrm{OPC}}$, is plotted as a function of $S S_{\mathrm{c}}$, both for ammonium sulphate particles (empirical fit from calibration data) and SOA. Error bars represent one standard deviation (described in Sect. 3.2). Rather than evaluating the absolute size of activated particles, the goal was to detect any differences between activated SOA and ammonium sulphate particles. $D_{\mathrm{OPC}}$ of SOA did not vary significantly from that of ammonium sulphate, implying that growth of $\beta$-caryophyllene SOA was not hindered. However, the lower size limit for detection in the OPC of the CF-CCNC is $750 \mathrm{~nm}$. If kinetic inhibition exist to an extent that growing droplets do not reach this size, different instrumentation would be needed to detect their water uptake.

Figure $10 \mathrm{a}-\mathrm{d}$ shows $D_{\mathrm{OPC}}$ as a function of time after the initial injection of $\beta$-caryophyllene for different dry particle diameters. For comparison $D_{\mathrm{OPC}}$ of activating ammonium sulphate particles are also shown for the same 
critical supersaturation (solid, horizontal lines). No trend beyond experimental uncertainty was observed for dark and lighted ozonolysis (Fig. 10a-b), but for ozonolysis in the presence of an $\mathrm{OH}$ scavenger a slight increase in $D_{\mathrm{OPC}}$ was observed as a function of time.

In Fig. 10a, data for $S S=1.32$ and $1.51 \%$ were measured in two different experiments, and some discrepancies were observed. This could be due to small changes in experimental conditions, such as the ambient temperature, on which the temperature in the growth chamber of the CF-CCNC depends, or the number concentration of activated particles. This seems only relevant for SOA, since $D_{\mathrm{OPC}}$ for ammonium sulphate was measured on different days without any notable variation (see Fig. 1). Asa-Awuku et al. (2009) observed an initial delay in activation kinetics, so that more than $6 \mathrm{~h}$ of chemical ageing were required for the growth kinetics of SOA particles to be comparable to those of ammonium sulphate. We do not see indications of delayed droplet growth kinetics, but it should be noted that we only have very few data during the first five hours after VOC injection, and that these data are for much higher supersaturations $(1.51 \%$ and $1.41 \%$ respectively) than those discussed by Asa-Awuku et al. ( $1.02 \%$ and $0.61 \%$ respectively). Furthermore, as already mentioned, if kinetic inhibition exists to an extent that growing droplets do not reach the lower size limit for detection in the OPC of the CF-CCNC of $750 \mathrm{~nm}$, different instrumentation is needed to detect their water uptake.

\section{Conclusions}

SOA generated from ozonolysis of $\beta$-caryophyllene and aged under exposure to various levels of $\mathrm{OH}$ radicals was characterized using two different $\mathrm{CCN}$ counters, one operating close to or below ambient room temperature and the other operating at higher temperatures (up to $51^{\circ} \mathrm{C}$ ). In all experiments, particles became progressively more $\mathrm{CCN}$ active when aged through exposure to $\mathrm{OH}$ and/or ozone. Fitting linear functions to $\kappa_{\mathrm{CCN}}$ as a function of time indicated that the increase was stronger for particles generated without exposure to light. $\kappa_{\mathrm{CCN}}$ depended heavily on exposure to $\mathrm{OH}$. It was lower in experiments carried out in the presence of an $\mathrm{OH}$ scavenger $\left(\kappa_{\mathrm{CCN}}<0.006\right.$ in experiments $\left.\mathrm{a}-\mathrm{b}\right)$ than in experiments with $\mathrm{OH}$ present $\left(\kappa_{\mathrm{CCN}}\right.$ in the range $0.002-0.16$ in the remaining experiments.), However, it is difficult to compare the different experiments, since $\mathrm{CCN}$ activity also depended on supersaturation in the $\mathrm{CCN}$ counters.

The TD data suggested that the CCN activity of SOA generated under dark conditions changed when SOA was exposed to temperatures of $35-50^{\circ}$, indicating that SOA contained semi-volatile material partially evaporating in the TD. This to some extent explained the supersaturation dependency of $\kappa_{\mathrm{CCN}}$, as measured by the $\mathrm{CF}-\mathrm{CCNC}$ because the elevated temperature applied at high supersaturations potentially removed hygroscopic material from the particles. In fu- ture studies, determining the volatility of $\beta$-caryophyllene SOA could provide a better understanding of this dependency. Yet, other explanations could involve a size dependency of the particle composition. Such effects are difficult to quantify, but could be examined further in future studies for example with online techniques, such as aerosol mass spectrometry or offline, through chemical characterization of filter samples.

Investigation of $\mathrm{CCN}$ activation kinetics revealed that growth and activation of aged SOA particles were comparable to those of ammonium sulphate particles and therefore not kinetically hindered.

Acknowledgements. This work was supported by the EC project EUROCHAMP-2 and PEGASOS as well as the Swiss National Science Foundation.

Edited by: J. Thornton

\section{References}

Alfarra, M. R., Hamilton, J. F., Wyche, K. P., Good, N., Ward, M. W., Carr, T., Barley, M. H., Monks, P. S., Jenkin, M. E., and McFiggans, G. B.: The effect of photochemical ageing and initial precursor concentration on the composition and hygroscopic properties of $\beta$-caryophyllene secondary organic aerosol, Atmos. Chem. Phys., 12, 6417-6436, doi:10.5194/acp-12-64172012, 2012.

Asa-Awuku, A. and Nenes, A.: Effect of solute dissolution kinetics on cloud droplet formation: Extended Köhler theory. J. Geophys. Res., 112, D22201, doi:10.1029/2005JD006934, 2007.

Asa-Awuku, A., Engelhart, G. J., Lee, B. H., Pandis, S. N., and Nenes, A.: Relating CCN activity, volatility, and droplet growth kinetics of $\beta$-caryophyllene secondary organic aerosol, Atmos. Chem. Phys., 9, 795-812, doi:10.5194/acp-9-795-2009, 2009.

Asa-Awuku, A., Nenes, A., Gao, S., Flagan, R. C., and Seinfeld, J. H.: Water-soluble SOA from alkene ozonolysis: composition and droplet activation kinetics inferences from analysis of CCN activity, Atmos. Chem. Phys., 10, 1585-1597, doi:10.5194/acp10-1585-2010, 2010.

Bilde, M. and Svenningsson, B.: CCN activation of slightly soluble organics: the importance of small amounts of inorganic salt and particle phase, Tellus B, 56, 128-134, doi:10.1111/j.16000889.2004.00090.x, 2004.

Burtscher, H., Baltensperger, U., Bukowiecki, N., Cohn, P., Hüglin, C., Mohr, M., Matter, U., Nyeki, S., Schmatloch, V., Streit, N., and Weingartner, E.: Separation of volatile and nonvolatile aerosol fractions by thermodesorption: instrumental development and applications, J. Aerosol Sci., 32, 427-442, doi:10.1016/S0021-8502(00)00089-6, 2001.

Chan, M. N., Surratt, J. D., Chan, A. W. H., Schilling, K., Offenberg, J. H., Lewandowski, M., Edney, E. O., Kleindienst, T. E., Jaoui, M., Edgerton, E. S., Tanner, R. L., Shaw, S. L., Zheng, M., Knipping, E. M., and Seinfeld, J. H.: Influence of aerosol acidity on the chemical composition of secondary organic aerosol from $\beta$-caryophyllene, Atmos. Chem. Phys., 11, 1735-1751, doi:10.5194/acp-11-1735-2011, 2011. 
Donahue, N. M., Huff-Hartz, K. E., Chuong, B., Presto, A. A., Stanier, C. O., Rosenørn, T., Robinson, A. L., and Pandis, S. N.: Critical factors determining the variation in SOA yields from terpene ozonolysis: A combined experimental and computational study, Faraday Discuss., 130, 295-309, doi:10.1039/B417369D, 2005.

Duplissy, J., Gysel, M., Alfarra, M. R., Dommen, J., Metzger, A., Prevot, A. S. H., Weingartner, E., Laaksonen, A., Raatikainen, T., Good, N., Turner, S. F., McFiggans, G., and Baltensperger, U.: Cloud forming potential of secondary organic aerosol under near atmospheric conditions, Geophys. Res. Lett., 35, L03818, doi:10.1029/2007GL031075, 2008.

Engelhart, G. J., Asa-Awuku, A., Nenes, A., and Pandis, S. N.: CCN activity and droplet growth kinetics of fresh and aged monoterpene secondary organic aerosol, Atmos. Chem. Phys., 8, 39373949, doi:10.5194/acp-8-3937-2008, 2008.

Frosch, M., Zardini, A. A., Platt, S. M., Müller, L., Reinnig, M.C., Hoffmann, T., and Bilde, M.: Thermodynamic properties and cloud droplet activation of a series of oxo-acids, Atmos. Chem. Phys., 10, 5873-5890, doi:10.5194/acp-10-5873-2010, 2010.

Frosch, M., Bilde, M., DeCarlo, P., Jurányi, Z., Tritscher, T., Dommen, J., Donahue, N. M., Gysel, M., Weingartner, E., and Baltensperger, U.: Relating CCN activity and oxidation level of $\alpha$-pinene secondary organic aerosol, J. Geophys. Res., 116, D22212, doi:10.1029/2011JD016401, 2011a.

Frosch, M., Prisle, N. L., Bilde, M., Varga, Z., and Kiss, G.: Joint effect of organic acids and inorganic salts on cloud droplet activation, Atmos. Chem. Phys., 11, 3895-3911, doi:10.5194/acp11-3895-2011, 2011b

Gao, S., Keywood, M., Ng, N. L., Surratt, J., Varutbangkul, V., Bahreini, R., Flagan, R. C., and Seinfeld, J. H.: Low-molecularweight and oligomeric components in secondary organic aerosol from the ozonolysis of cycloalkenes and alpha-pinene, J. Phys. Chem. A, 108, 10147-10164, doi:10.1021/jp047466e, 2004.

Goldstein, A. H. and Galbally, I. E.: Known and unexplored organic constituents in the Earth's atmosphere, Environ. Sci. Technol., 41, 1514-1521, doi:10.1021/es072476p, 2007.

Griffin, R. J., Cocker III, D. R., Seinfeld, J. H., and Dabdub, D.: Estimate of global atmospheric organic aerosol from oxidation of biogenic hydrocarbons, Geophys. Res. Lett., 26, 2721-2724, doi:10.1029/1999GL900476, 1999.

Guenther, A., Hewitt, N. C., Erickson, D., Fall, R., Geron, C., Graedel, T., Harley, P., Klinger, L., Lerdau, M., McKay, W. A., Pierce, T., Scholes, B., Steinbrecher, R., Tallamraju, R., Taylor, J., and Zimmerman, P.: A global model of natural volatile organic compound emissions, J. Geophys. Res., 100, 8873-8892, doi: 10.1029/94JD02950, 1995.

Hallquist, M., Wenger, J. C., Baltensperger, U., Rudich, Y., Simpson, D., Claeys, M., Dommen, J., Donahue, N. M., George, C., Goldstein, A. H., Hamilton, J. F., Herrmann, H., Hoffmann, T., Iinuma, Y., Jang, M., Jenkin, M. E., Jimenez, J. L., Kiendler-Scharr, A., Maenhaut, W., McFiggans, G., Mentel, Th. F., Monod, A., Prévôt, A. S. H., Seinfeld, J. H., Surratt, J. D., Szmigielski, R., and Wildt, J.: The formation, properties and impact of secondary organic aerosol: current and emerging issues, Atmos. Chem. Phys., 9, 5155-5236, doi:10.5194/acp-9-51552009, 2009.

Hamilton, J. F., Rami Alfarra, M., Wyche, K. P., Ward, M. W., Lewis, A. C., McFiggans, G. B., Good, N., Monks, P. S., Carr, T.,
White, I. R., and Purvis, R. M.: Investigating the use of secondary organic aerosol as seed particles in simulation chamber experiments, Atmos. Chem. Phys., 11, 5917-5929, doi:10.5194/acp11-5917-2011, 2011.

Hoffmann, T., Odum, J. R., Bowman, F., Collins, D., Klockow, D., Flagan, R. C., and Seinfeld, J. H.: Formation of organic aerosols from the oxidation of biogenic hydrocarbons, J. Atmos. Chem., 26, 189-222, doi:10.1023/A:1005734301837, 1997.

Huff-Hartz, K. E.., Rosenørn, T., Ferchak, S. R., Raymond, T. M., Bilde, M., Donahue, N. M., and Pandis, S. N.: Cloud condensation nuclei activation of monoterpene and sesquiterpene secondary organic aerosol, J. Geophys. Res., 110, D14208, doi:10.1029/2004jd005754, 2005.

IPCC: Climate Change 2007: The Physical Science Basis. Contribution of Working Group I to the Fourth Assessment Report of the Intergovernmental Panel on Climate Change, Cambridge University Press, Cambridge, UK, 2007.

Jang, M. and Kamens, R. M.: Atmospheric secondary aerosol formation by heterogeneous reactions of aldehydes in the presence of a sulfuric acid aerosol catalyst, Environ. Sci. Technol., 35, 4758-4766, doi:10.1021/es010790s, 2001.

Jaoui, M., Leungsakul, S., and Kamens, R. M.: Gas and particle products distribution from the reaction of $\beta$ caryophyllene with ozone, J. Atmos. Chem., 45, 261-287, doi:10.1023/A:1024263430285, 2003.

Jenkin, M. E., Wyche, K. P., Evans, C. J., Carr, T., Monks, P. S., Alfarra, M. R., Barley, M. H., McFiggans, G. B., Young, J. C., and Rickard, A. R.: Development and chamber evaluation of the MCM v3.2 degradation scheme for $\beta$-caryophyllene, Atmos. Chem. Phys., 12, 5275-5308, doi:10.5194/acp-12-52752012, 2012.

Jimenez, J. L., Canagaratna, M. R., Donahue, N. M., Prevot, A. S. H., Zhang, Q., Kroll, J. H., DeCarlo, P. F., Allan, J. D., Coe, H., Ng, N. L., Aiken, A. C., Docherty, K. S., Ulbrich, I. M., Grieshop, A. P., Robinson, A. L., Duplissy, J., Smith, J. D., Wilson, K. R., Lanz, V. A., Hueglin, C., Sun, Y. L., Tian, J., Laaksonen, A., Raatikainen, T., Rautiainen, J., Vaattovaara, P., Ehn, M., Kulmala, M., Tomlinson, J. M., Collins, D. R., Cubison, M. J., Dunlea, E. J., Huffman, J. A., Onasch, T. B., Alfarra, M. R., Williams, P. I., Bower, K., Kondo, Y., Schneider, J., Drewnick, F., Borrmann, S., Weimer, S., Demerjian, K., Salcedo, D., Cottrell, L., Griffin, R., Takami, A., Miyoshi, T., Hatakeyama, S., Shimono, A., Sun, J. Y., Zhang, Y. M., Dzepina, K., Kimmel, J. R., Sueper, D., Jayne, J. T., Herndon, S. C., Trimborn, A. M., Williams, L. R., Wood, E. C., Middlebrook, A. M., Kolb, C. E., Baltensperger, U., and Worsnop, D. R.: Evolution of organic aerosols in the atmosphere, Science, 326, 1525-1529, doi:10.1126/science.1180353, 2009.

Jurányi, Z., Gysel, M., Duplissy, J., Weingartner, E., Tritscher, T., Dommen, J., Henning, S., Ziese, M., Kiselev, A., Stratmann, F., George, I., and Baltensperger, U.: Influence of gas-to-particle partitioning on the hygroscopic and droplet activation behaviour of alpha-pinene secondary organic aerosol. Phys. Chem. Chem. Phys., 11, 8091-8097, doi:10.1039/B904162A, 2009.

Kanakidou, M., Seinfeld, J. H., Pandis, S. N., Barnes, I., Dentener, F. J., Facchini, M. C., Van Dingenen, R., Ervens, B., Nenes, A., Nielsen, C. J., Swietlicki, E., Putaud, J. P., Balkanski, Y., Fuzzi, S., Horth, J., Moortgat, G. K., Winterhalter, R., Myhre, C. E. L., Tsigaridis, K., Vignati, E., Stephanou, E. G., and Wilson, 
J.: Organic aerosol and global climate modelling: a review, Atmos. Chem. Phys., 5, 1053-1123, doi:10.5194/acp-5-1053-2005, 2005.

Kleindienst, T. E., Jaoui, M., Lewandowski, M., Offenberg, J. H., Lewis, C. W., Bhave, P. V., and Edney, E. O.: Estimates of the contributions of biogenic and anthropogenic hydrocarbons to secondary organic aerosol at a southeastern US location, Atmos. Environ., 41, 8288-8300, doi:10.1016/j.atmosenv.2007.06.045, 2007.

Köhler, H.: The nucleus in and the growth of hygroscopic droplets, T. Faraday Soc., 32, 1152-1161, doi:10.1039/TF9363201152, 1936.

Kuwata, M., Chen, Q., and Martin, S. T.: Cloud condensation nuclei $(\mathrm{CCN})$ activity and oxygen-to-carbon elemental ratios following thermodenuder treatment of organic particles grown by $\alpha$ pinene ozonolysis, Phys. Chem. Chem. Phys., 13, 14571-14583, doi:10.1039/c1cp20253g, 2011.

Lance, S., Medina, J., Smith, J. N., and Nenes, A.: Mapping the operation of the DMT continuous flow CCN counter, Aerosol Sci. Technol., 40, 242-254, doi:10.1080/02786820500543290, 2006.

Lathem, T. L. and Nenes, A.: Water vapor depletion in the DMT continuous-flow CCN chamber: Effects on supersaturation and droplet growth, Aerosol Sci. Technol., 45, 604-615, doi:10.1080/02786826.2010.551146, 2011.

Lee, A., Goldstein, A. H., Keywood, M. D., Gao, S., Varutbangkul, V., Bahreini, R., Ng, N. L., Flagan, R. C., and Seinfeld, J. H.: Gas-phase products and secondary aerosol yields from the ozonolysis of ten different terpenes, J. Geophys. Res., 111, D07302, doi:10.1029/2005jd006437, 2006.

Li, Z., Williams, A. L., and Rood, M. J.: Influence of soluble surfactant properties on the activation of aerosol particles containing inorganic solute, J. Atmos. Sci., 55, 1859-1866, doi:10.1175/1520-0469(1998)055<1859:IOSSPO > 2.0.CO;2, 1998.

Nenes, A., Ghan, S., Abdul-Razzak, H., Chuang, P. Y., and Seinfeld, J. H.: Kinetic limitations on cloud droplet formation and impact on cloud albedo, Tellus B, 53, 133-149, doi:10.1034/j.16000889.2001.d01-12.x, 2001.

Paulsen, D., Dommen, J., Kalberer, M., Prévôt, A. S. H., Richter, R., Sax, M., Steinbacher, M., Weingartner, E., and Baltensperger, U.: Secondary organic aerosol formation by irradiation of $1,3,5-$ trimethylbenzene- $\mathrm{NO}_{\mathrm{x}}-\mathrm{H}_{2} \mathrm{O}$ in a new reaction chamber for atmospheric chemistry and physics, Environ. Sci. Technol., 39, 2668-2678, doi:10.1021/es0489137, 2005.

Petters, M. D. and Kreidenweis, S. M.: A single parameter representation of hygroscopic growth and cloud condensation nucleus activity, Atmos. Chem. Phys., 7, 1961-1971, doi:10.5194/acp-71961-2007, 2007.

Prenni, A. J., Petters, M. D., Kreidenweis, S. M., DeMott, P. J., and Ziemann, P. J.: Cloud droplet activation of secondary organic aerosol, J. Geophys. Res., 112, D10223, doi:10.1029/2006jd007963, 2007.

Prisle, N. L., Raatikainen, T., Sorjamaa, R., Svenningsson, B., Laaksonen, A., and Bilde, M.: Surfactant partitioning in cloud droplet activation: A study of C8, C10, C12 and C14 normal fatty acid sodium salts, Tellus B, 60, 416-431, doi:10.1111/j.16000889.2008.00352.x, 2008.

Raatikainen, T., Moore, R. H., Lathem, T. L., and Nenes, A.: A coupled observation - modeling approach for studying activation ki- netics from measurements of CCN activity, Atmos. Chem. Phys., 12, 4227-4243, doi:10.5194/acp-12-4227-2012, 2012.

Riipinen, I. Pierce, J. R., Donahue, N. M., and Pandis, S. N.: Equilibration time scales of organic aerosol inside thermodenuders: Evaporation kinetics versus thermodynamics, Atmos. Environ., 44, 597-607, doi:10.1016/j.atmosenv.2009.11.022, 2010.

Rissler, J., Vestin, A., Swietlicki, E., Fisch, G., Zhou, J., Artaxo, P., and Andreae, M. O.: Size distribution and hygroscopic properties of aerosol particles from dry-season biomass burning in Amazonia, Atmos. Chem. Phys., 6, 471-491, doi:10.5194/acp-6-4712006,

Roberts, G. C. and Nenes, A.: A continuous-flow streamwise thermal-gradient $\mathrm{CCN}$ chamber for atmospheric measurements, Aerosol Sci. Technol., 39, 206-221, doi:10.1080/027868290913988, 2005.

Sakulyanontvittaya, T., Guenther, A., Helmig, D., Milford, J., and Wiedinmyer, C.: Secondary organic aerosol from sesquiterpene and monoterpene emissions in the United States, Environ. Sci. Technol., 42, 8784-8790, doi:10.1021/es800817r, 2008.

Seinfeld, J. H. and Pandis, S. N. Atmospheric Chemistry and Physics. From Air Pollution to Climate Change, 2nd edition, Wiley Interscience Publications, John Wiley \& Sons, New York, USA, 2006.

Sjogren, S., Gysel, M., Weingartner, E., Baltensperger, U., Cubison, M. J., Coe, H., Zardini, A. A., Marcolli, C., Krieger, U. K., and Peter, T.: Hygroscopic growth and water uptake kinetics of two-phase aerosol particles consisting of ammonium sulfate, adipic and humic acid mixtures, J. Aerosol Sci., 38, 157-171, doi:10.1016/j.jaerosci.2006.11.005, 2007.

Snider, J. R., Petters, M. D., Wechsler, P., and Liu, P. S. K.: Supersaturation in the Wyoming CCN Instrument, J. Atmos. Ocean. Tech., 23, 1323-1339, doi:10.1175/JTECH1916.1, 2006.

Snider, J. R., Wex, H., Rose, D., Kristensson, A., Stratmann, F., Hennig, T., Henning, S., Kiselev, A., Bilde, M., Burkhart, M., Dusek, U., Frank, G. P., Kiendler-Scharr, A., Mentel, T. F., Petters, M. D., and Pöschl, U.: Intercomparison of cloud condensation nuclei and hygroscopic fraction measurements: Coated soot particles investigated during the LACIS Experiment in November (LExNo). J. Geophys. Res., 115, D11205, doi:10.1029/2009JD012618, 2010.

Sorjamaa, R., Svenningsson, B., Raatikainen, T., Henning, S., Bilde, M., and Laaksonen, A.: The role of surfactants in Köhler theory reconsidered, Atmos. Chem. Phys., 4, 2107-2117, doi:10.5194/acp-4-2107-2004, 2004.

Svenningsson, B. and Bilde, M.: Relaxed step functions for evaluation of CCN counter data on size-separated aerosol particles, J. Aerosol Sci., 39, 592-608, doi:10.1016/j.jaerosci.2008.03.004, 2008.

Taira, M. and Kanda, Y.: Continuous generation system for lowconcentration gaseous nitrous acid, Anal. Chem., 62, 630-633, doi:10.1021/ac00205a018, 1990.

Tang, X., Cocker III, D. R., and Asa-Awuku, A.: Are sesquiterpenes a good source of secondary organic cloud condensation nuclei (CCN)? Revisiting $\beta$-caryophyllene CCN, Atmos. Chem. Phys., 12, 8377-8388, doi:10.5194/acp-12-8377-2012, 2012.

Tritscher, T., Dommen, J., DeCarlo, P. F., Gysel, M., Barmet, P. B., Praplan, A. P., Weingartner, E., Prévôt, A. S. H., Riipinen, I., Donahue, N. M., and Baltensperger, U.: Volatility and hygroscopicity of aging secondary organic aerosol in a smog cham- 
ber, Atmos. Chem. Phys., 11, 11477-11496, doi:10.5194/acp11-11477-2011, 2011.

Wex, H., Hennig, T., Salma, I., Ocskay, R., Kiselev, A., Henning, S., Massling, A., Wiedensohler, A., and Stratmann, F.: Hygroscopic growth and measured and modeled critical super-saturations of an atmospheric HULIS sample, Geophys. Res. Lett., 34, L02818, doi:10.1029/2006GL028260, 2007. 